\title{
Studia
}

\author{
Jagoda Klimala ${ }^{\text {a) }}$ \\ (D) https://orcid.org/0000-0002-2766-884X
}

\section{Regionalne ujednolicenie prawa prywatnego międzynarodowego w Skandynawii ze szczególnym uwzględnieniem spraw spadkowych}

\begin{abstract}
The aim of the following article is to introduce characteristics of the Nordic countries' cooperation in the field of private international law, with particular emphasis on legislative cooperation concerning matters of inheritance law. The study discusses the genesis, characteristics and methods of legislative cooperation, along with selected Nordic conventions on private international law. As an example of a legal act of such kind, the article presents the Convention of 19 November 1934 comprising private international law provisions on succession, wills and estate administration, the detailed analysis of which was based on the author's translation of the act from Swedish to Polish. Selected detailed issues discussed in the content of the Convention were also presented, some of which were compared to the solutions adopted by Regulation (EU) No 650/2012 of the European Parliament and of the Council of 4 July 2012.
\end{abstract}

Keywords: Nordic cooperation — Nordic inheritance convention — Nordic Council

\footnotetext{
a) Mgr, Uniwersytet Jagielloński.
} 


\section{Uwagi wstępne}

Korzenie i historia współpracy skandynawskiej ${ }^{1}$ dowodzą, że działania legislacyjne w ramach Rady Nordyckiej (szw. Nordiska rådet) ${ }^{2}$ — podobnie jak między państwami Beneluksu — postrzegać można jako etap wstępny współczesnej współpracy sądowej między państwami członkowskimi Unii Europejskiej. Państwa leżące na północ od Polski wykształciły pewnego rodzaju wyjątkowy model współpracy, oparty na niepowszechnych mechanizmach, zasługujący na dokładniejsze omówienie. Dostępna literatura tematyczna, poza pozycjami w językach narodowych państw nordyckich, nie jest obfita w źródła, które w sposób kompleksowy opisują naturę współpracy nordyckiej, szczególnie zaś współpracy prawnej. Co więcej, ze względu na zaangażowanie części regionu w integrację europejską, ciekawym zagadnieniem są również nordyckie procesy integracyjne, obejmujące zawieranie umów międzynarodowych między tymi państwami, a także unifikacja prawa w nich obowiązującego oraz ich relacja do postępującej europeizacji prawa. Współpraca nordycka nie jest tematem tak odległym od kwestii i problemów istniejących z perspektywy polskiego porządku prawnego, jak mogłoby się wydawać. Poza bliskością geograficzną, podobieństwo Polski do Szwecji i Finlandii sprowa-

${ }^{1}$ Skandynawia jest regionem obejmującym Danię, Norwegię oraz Szwecję, tj. państwa leżące w obrębie Półwyspu Skandynawskiego. Do państw nordyckich zaliczane są natomiast wspomniane państwa skandynawskie, a także Finlandia, Islandia oraz terytoria autonomiczne - Wyspy Owcze i Grenlandia, należące do Danii, oraz Wyspy Alandzkie, będące szwedzkojęzyczną jednostką administracyjną Finlandii. Termin „prawo skandynawskie” jest jednak powszechnie używany w nauce prawa oraz komparatystyce (szczegółowe uwagi terminologiczne zob. U. Bernitz, What is Scandinavian Law?, „Scandinavian Studies in Law” 2007, vol. 50, s. 14). Jednakże określenie tej grupy państw jako „państwa nordyckie” wydaje się właściwsze, ponieważ pokazuje szerokie spektrum powiązań między nimi, obejmujących więcej niż aspekt położenia geograficznego, a także odpowiada terminologii określającej ich wspólne instytucje.

${ }^{2}$ Współpraca państw nordyckich rozwijała się przez ponad sto lat wspólnych przedsięwzięć. Początki nowego rozdziału historii, jakim jest integracja nordycka, sięgają przełomu XIX i XX w., chociaż już kilkadziesiąt lat wcześniej pojawiła się koncepcja zwana skandynawizmem. Zakładała ona powrót do tradycji Unii Kalmarskiej, czyli ściślejszą współpracę państw skandynawskich, które miałyby stać się potęgą na politycznej mapie Europy. W połowie XX w. państwa nordyckie zdecydowały o potrzebie instytucjonalizacji współpracy. W 1952 r. Dania, Szwecja, Norwegia i Islandia utworzyły Radę Nordycką, do której Finlandia dołączyła w roku 1995. Rada w założeniu miała stanowić forum międzyparlamentarne, pogłębiające nordycką integrację, jednocześnie nadając jej oficjalne ramy. Zob. więcej Z. Klepacki, R. Ławniczak, Rada Nordycka a wspótpraca $i$ integracja państw skandynawskich, Polski Instytut Spraw Międzynarodowych, Warszawa, 1976, s. 17 i n. 
dza się do obowiązywania w nich rozporządzeń unijnych, a w przypadku Danii (która jest państwem członkowskim UE, ale zasadniczo nie uczestniczy we „współpracy sądowej w sprawach cywilnych”) i Norwegii wiążą Polskę konwencje lugańskie ${ }^{3}$.

Przybliżenia modelu współpracy, jaki państwa nordyckie przyjęły w procesie ujednolicenia prawa prywatnego, warto dokonać ze szczególnym uwzględnieniem zagadnień należących do zakresu prawa prywatnego międzynarodowego. Za przykład nordyckiego aktu normatywnego ilustrujący złożoność regionalnego systemu współpracy legislacyjnej państw nordyckich może posłużyć nordycka konwencja spadkowa (szw. Den nordiska arvkonventionen), której treść omówiona zostanie na podstawie autorskiego tłumaczenia z języka szwedzkiego ${ }^{4}$.

\section{Współpraca państw nordyckich na gruncie prawa prywatnego}

Pojęcie „prawo nordyckie” bądź „prawo skandynawskie” może być przede wszystkim rozumiane jako zbiorcza kategoria obejmująca systemy prawa krajowego poszczególnych państw nordyckich, wraz z aktami normatywnymi o charakterze międzynarodowym zawartymi między tymi państwami.

Wspólne korzenie językowe ${ }^{5}$, historia, tradycje, kultura oraz relatywnie korzystna sytuacja ekonomiczna państw nordyckich, a także podobne cele społeczno-polityczne umożliwiają dzisiejszą efektywną współpracę, opartą na zasadach partnerskiej kooperacji, poszanowania demokratycznych wartości oraz wzajemnego zaufania.

Ze względu na specyfikę prawa nordyckiego jego kwalifikacja jako należącego do systemu prawa kontynentalnego bądź systemu common

${ }^{3}$ Zob. więcej P. Mostowik, M. Niedźwiedź, Druga konwencja lugańska o jurysdykcji oraz uznawaniu $i$ wykonywaniu orzeczen $w$ sprawach cywilnych, „Kwartalnik Prawa Prywatnego" 2009, z. 4, s. 990 i n. oraz P. Mostowik, Międzynarodowe prawo prywatne $i$ postępowanie cywilne $w$ dekade po wejściu w życie Traktatu Amsterdamskiego, „Przegląd Sądowy" 2010, z. 2, s. 47-48.

${ }^{4}$ Tłumaczenie tekstu Konwencji, autorstwa Jagody Klimali, zostało opublikowane w niniejszym tomie „Problemów Prawa Prywatnego Międzynarodowego”, w dziale Materiaty.

${ }^{5}$ Podobieństwo języków nordyckich oraz powszechna znajomość języka szwedzkiego w Finlandii znacznie ograniczają problemy komunikacyjne oraz terminologiczne w tworzeniu i tłumaczeniu aktów prawnych. 
law wydaje się nieoczywista. W nauce prawa proponowano m.in. przyporządkowanie prawa nordyckiego do germańskiego odłamu systemu prawa kontynentalnego lub traktowanie go jako oddzielną grupę bądź podgrupę europejskich porządków prawnych ${ }^{6}$. Pomimo trudności w jednoznacznej odpowiedzi na pytanie, do jakiego systemu zakwalifikować prawo skandynawskie, możliwe jest wyodrębnienie grupy cech dla niego charakterystycznych. Jedną z nich jest brak rozwiniętej kodyfikacji, nawet na gruncie prawa prywatnego, przy jednoczesnym oparciu porządku prawnego na źródłach prawa stanowionego. Nordyckie prawodawstwo cechuje podejście bardziej pragmatyczne i powściągliwe w porównaniu z kompleksowymi oraz systemowymi regulacjami praktykowanymi przez prawo kontynentalne. W miejsce kodeksów preferowane są krótkie akty prawne ograniczające do minimum kazuistykę. Istotny wpływ na kształt dzisiejszego prawa skandynawskiego wywarła również znacząca pozycja praktyków prawa, niemających profesjonalnego wykształcenia w zakresie nauk prawnych ${ }^{8}$, a także rola, jaką dla stosowania prawa i interpretacji aktów prawnych przez sądy mają prace przygotowawcze

${ }^{6}$ Proponowane są również podejścia klasyfikujące system prawa skandynawskiego jako jeden z mieszanych porządków prawnych, stojących w opozycji do tradycyjnego podziału na prawo stanowione i precedensowe. Konrad Zweigert oraz Hein Kötz wyróżnili prawo skandynawskie, obok systemów prawa romańskiego, germańskiego, anglosaskiego oraz praw państw Bliskiego i Dalekiego Wschodu. Zob. więcej P. Letto-Vanamo, D. Tamm, Nordic Legal Mind, in: Nordic Law in European Context, eds. P. Letto-Vanamo, D. Tamm, B.O.G. Mortensen, „Ius Gentium: Comparative Perspectives on Law and Justice Volume" 2019, 73, s. 7; por. J. Husa, K. Nuotio, H. Pihlajamäki, Nordic Law - Between Tradition and Dynamism, ,Tilburg Institute of Comparative and Transnational Law Working Paper" 2008, no. 10, s. $5-12$.

7 Przyczyny determinujące postępującą kodyfikację w państwach Europy kontynentalnej nie miały uzasadnienia w skandynawskich realiach, gdzie nie występował problem mozaiki źródeł obowiązującego prawa - ze względu na brak klasowej struktury społecznej i wykształcenia odrębnych praw miejskich, a także na ograniczone wpływy prawa rzymskiego oraz niewielką rolę prawa kanonicznego. Dopiero na przełomie XVII i XVIII w. w państwach skandynawskich zaczęły pojawiać się akty prawne mające charakter kodyfikacji - Danske Lov z 1683 r., Norske Lov z 1687 r. czy szwedzki kodeks cywilny - 1734 års lag, które nie były jednak rozbudowane w takim stopniu, jak pozostałe kodeksy europejskie. Zob. więcej J. Husa, K. Nuotio, H. Pihlajamäki, Nordic Law..., s. $12-14$ oraz s. $24-25$.

8 Zjawisko sięgające korzeniami czasów średniowiecza - z uwagi na niedobór wykwalifikowanych prawników. Wpływy europejskie zdeterminowały pewne zmiany w tym obszarze w kolejnych wiekach, jednakże rola niewykwalifikowanych sędziów nie pozostała bez znaczenia dla dalszego rozwoju skandynawskiego porządku prawnego oraz nurtów skandynawskiej myśli prawniczej — np. skandynawski realizm prawniczy oraz pragmatyczne podejście do postrzegania roli prawa. Zob. więcej J. Husa, K. Nuotio, H. Pihlajamäki, Nordic Law..., s. 20-23. 
oraz motywy ustawodawcy w procesie legislacyjnym, przy jednoczesnym ograniczeniu znaczenia doktryny ${ }^{9}$.

Długoletnia tradycja w procesie kreowania modelu nordyckiej współpracy legislacyjnej pozwoliła na wykształcenie oraz ewolucję różnorodnych jej form, z których niejednokrotnie korzysta się po dziś dzień. Wypracowane przez państwa nordyckie rozwiązania cechuje interesująca charakterystyka. Pierwsze próby harmonizacji prawa między Szwecją, Danią i Norwegią podjęto w roku 1872. Wtedy też miało miejsce pierwsze z serii spotkań nordyckich przedstawicieli nauki prawa oraz praktyki prawniczej, których tradycja znajduje swoje źródła w niemieckich wzorcach oraz kontynuowana jest do dziś. Z początku miały one charakter nieformalny, były platformą stworzoną dla środowisk akademickich. Pozwoliły także na umacnianie pozycji nordyckiej nauki prawa oraz w pewnym stopniu przyczyniły się do nadania prawu skandynawskiemu wyraźniejszych cech charakterystycznych, a w konsekwencji do wyodrębnienia go jako osobnej kategorii ${ }^{10}$. Spotkania te stanowiły nie tylko forum dyskusji i wymiany myśli między znawcami prawa. Inicjowały również projektowanie oraz wprowadzanie regulacji prawnych. W każdym z państw nordyckich prywatnoprawne akty pod koniec XIX w. uchwalane były $\mathrm{w}$ niemal jednakowym brzmieniu ${ }^{11}$. W pierwszych dekadach $\mathrm{XX}$ w. nordycka kooperacja przyniosła rezultat w postaci serii traktatów, z których część wciąż pozostaje w mocy. Kolejną formą współpracy było tworzenie w każdym z państw współpracujących z sobą komitetów, których zadaniem było przygotowywanie projektów aktów prawnych. Współpraca w ramach wskazanej formy ma miejsce do dnia dzisiejszego. Przybiera postać konsultacji międzypaństwowych, których celem jest ustanowienie możliwie podobnego do siebie prawa w poszczególnych państwach. Przeważnie jednak konsultacje te nie prowadzą do opracowania jednej ponadpaństwowej regulacji lub projektu aktu podlegającego implementacji w każdym z państw ${ }^{12}$. Obecnie prace tego rodzaju komitetów odbywają się głównie w ramach i na forum Rady Nordyckiej oraz Nordyckiej Rady Ministrów ${ }^{13}$.

${ }^{9}$ U. Bernitz, What is..., s. 43-44.

10 J. Husa, K. Nuotio, H. Pihlajamäki, Nordic Law..., s. 26.

11 Głównie ze względu na dynamiczny rozwój handlu międzynarodowego. W tym miejscu należy wymienić prawo weksli, czeków, znaków towarowych czy kodeksy morskie, a idąc nieco dalej, kodeksy handlowe oraz prawo umów wprowadzane z początkiem XX w. Zob. więcej P. Letto-Vanamo, D. Tamm, Nordic Legal Mind..., s. 3.

12 S. Blomstrand, Nordic Co-operation on Legislation in the Field of Private Law, „Scandinavian Studies in Law” 2000, vol. 39, s. 59-62.

${ }^{13}$ W językach skandynawskich współdziałanie państw w ramach obu Rad określane jest jako Nordiskt Samarbete (szw.), co tłumaczyć można bezpośrednio jako Nordycka Współpraca. Oddaje to charakter nordyckiej kooperacji, a także odzwierciedla skandy- 
Chociaż państwa nordyckie zmierzały do ujednolicenia reguł prawa prywatnego już przed powołaniem Rady Nordyckiej, dopiero Traktat z Helsinek ${ }^{14}$ w 1962 r. nadał współpracy w tej dziedzinie wyraźną podstawę prawną. Akt ten zakreślił ramy współpracy, wyznaczył konkretne cele oraz podstawy funkcjonowania struktur organizacji, a jego postanowienia zobowiązały państwa członkowskie do rozwijania współpracy na gruncie legislacji, stanowiącej pierwszy wymieniony w Traktacie obszar kooperacji. Artykuł 4 Traktatu stanowi, że państwa umawiające się powinny kontynuować współpracę w obszarze prawa, ze szczególnym uwzględnieniem działań na rzecz uzyskania możliwie najszerszej unifikacji przepisów prawa prywatnego w każdym z państw. Kompleksowy charakter integracji nordyckiej rzutował na wyjście owej współpracy poza ramy prywatnoprawne. Kolejny artykuł sygnalizuje konieczność współdziałania w ujednoliceniu niektórych norm prawa karnego $^{15}$. W treści aktu wskazano również na możliwość unifikacji reguł prawnych w innych niż karno- i prywatnoprawnych obszarach, jeśli wydaje się to celowe. Traktat konstytuuje także zasadę uznawania i wykonywania orzeczeń sądów krajowych pomiędzy państwami nordyckimi ${ }^{16}$. Państwa te wcielają w życie zasady ustanowione Traktatem przez aktywną współpracę na forum Nordyckiej Rady Ministrów. Prace w komitetach do spraw legislacji pozwalają na wprowadzanie jednolitych bądź podobnych przepisów prawa, z poszanowaniem specyfiki i odrębności krajowych porządków prawnych. Od czasu instytucjonalizacji współpracy nordyckiej grupy ekspertów pracują również nad nowelizacją konwencji nordyckich zawieranych już na początku XX w., a także opracowują akty zastępujące owe konwencje. Nordycka Rada Ministrów za pośrednictwem komitetów wydaje też publikacje zawierające obszerne wyjaśnienia motywów wspomnianych zmian aktów normatywnych oraz komentarz do reguł prawnych $\mathrm{w}$ nich zawartych ${ }^{17}$.

nawskie pojmowanie celów, dla których państwa te zdecydowały się zrzeszyć, https:// www.norden.org/sv/organisation/nordiskt-samarbete [Dostęp: 31.08.2021 r.].

${ }_{14}$ The Helsinki Treaty (2018:746).

15 Dotyczy typów czynów zabronionych oraz kar grożących za ich popełnienie, a także umożliwienia przeprowadzenia śledztwa bądź dochodzenia oraz procesu karnego w każdym państwie nordyckim za przestępstwo popełnione w jednym z nich.

${ }^{16}$ Art. 4-7, The Helsinki Treaty (2018:746).

17 Przykładem może być obszerna publikacja na temat porozumienia o zmianie nordyckiej konwencji spadkowej, dostępna na stronie internetowej Rady Nordyckiej: Den nordiska konventionen om arv, testamente och boutredning (antagen $i$ Köpenhamn 19.11.1934) En översyn av konventionsregleringen föreslagen av den nordiska expertgruppen för familjerättsfrågor, Nordiska ministerrådet, TemaNord 2013:528, https://www. norden.org/sv/node/6068 [Dostęp: 31.08.2021 r.]. 
Jednym z najistotniejszych czynników wpływających na porządek prawny państw nordyckich ma członkostwo w Unii Europejskiej. Europeizacja prawa, w tym materialnego prawa prywatnego państw członkowskich UE, ma znaczący wpływ również na prawo krajowe państw nordyckich. Oczywiście kwestia ta jest relewantna dla tych państw nordyckich, które należą do Unii Europejskiej. Jednakże można zauważyć, że integracja europejska wpływa także na współpracę prawną państw nordyckich, które niejednokrotnie są zmuszone do rewizji regionalnych porozumień lub dostosowywania kierunków swojej współpracy adekwatnie do kierunku obranego przez Unię Europejską.

\section{Umowa międzynarodowa jako środek ujednolicenia norm prawa prywatnego międzynarodowego}

Na przestrzeni ponad stuletniej współpracy prawnej zawarto szereg aktów, będących konwencjonalnymi traktatami międzynarodowymi, których celem jest określenie wolności i precyzyjne wskazanie obowiązków państw umawiających się w kontekście międzynarodowego prawa publicznego ${ }^{18}$. Tytułem przykładu można wskazać wspomniany wcześniej Traktat z Helsinek. Państwa nordyckie zawierały również umowy międzynarodowe, których celem było poszerzanie współpracy o kolejne obszary, a także ujednolicenie konkretnej gałęzi prawa lub szczegółowych zagadnień. Na mocy nordyckiej konwencji utworzono unię paszportową i wspólny rynek pracy ${ }^{19}$. Przykładem interesującego porozumienia może być także Nordycka konwencja językowa ${ }^{20}$, gwarantująca prawo posługiwania się swoim językiem ojczystym w kontaktach z aparatem państwowym innego państwa nordyckiego. Przykładami umów unifikujących prawo materialne w państwach nordyckich są konwencje w takich dziedzinach, jak ubezpieczenia społeczne, jednolite prawo patentowe, ochrona środowiska czy przyznanie obywatelom innego państwa nor-

${ }_{18}$ M. Czepelak, Umowa międzynarodowa jako źródto prawa prywatnego międzynarodowego, Oficyna a Wolters Kluwer business, 2008, s. 12 i n., https://sip.lex.pl/\#/ monograph/369182464/11 [Dostęp: 31.08.2021 r.].

19 Wersje aktów w języku angielskim można znaleźć na stronie: https://www.norden. org/en/information/nordic-agreements-and-legislation [Dostęp: 31.08.2021 r.].

${ }^{20}$ Konvention mellan Sverige, Danmark, Finland, Island och Norge om nordiska medborgares rätt att använda sitt eget språk i annat nordiskt land, Svaneke den 17 juni 1981 (SÖ 1982:93). 
dyckiego czynnego i biernego prawa wyborczego do organów samorządów lokalnych ${ }^{21}$.

Dyscypliną prawną, nad którą państwa nordyckie pochylały się już na etapie tworzenia pierwszych konwencji, było międzynarodowe prawo prywatne. W celu zobrazowania złożoności problemu, jakim jest stosowanie norm prawa prywatnego międzynarodowego ustanowionych $\mathrm{w}$ ramach współpracy nordyckiej, warto przedstawić pokrótce system prawa prywatnego międzynarodowego jednego z państw nordyckich. Charakterystyka szwedzkiego systemu prawa prywatnego międzynarodowego ilustruje złożoność zagadnień, jakie pojawiają się w kontekście nordyckiej współpracy w tym obszarze oraz konsekwencji dla krajowych porządków prawnych. Wielość źródeł prawa prywatnego międzynarodowego stwarza istotne problemy praktyczne. Rezultatem członkostwa Szwecji w Unii Europejskiej, a tym samym związania europejskim prawem $\mathrm{w}$ zakresie współpracy sądowej w sprawach cywilnych, jest wyparcie z zastosowania $\mathrm{w}$ określonych obszarach krajowych norm kolizyjnych przez normy unijne. Ponadto, Szwecja związana jest umowami międzynarodowymi, z których szczególne znaczenie mają konwencje opracowane przez Haską Konferencję Prawa Prywatnego Międzynarodowego ${ }^{22}$. Należy też wskazać, że wciąż istnieje regionalny system prawa prywatnego międzynarodowego w niektórych dziedzinach prawa kreowany przez konwencje zawarte między państwami nordyckimi ${ }^{23}$. System ten, szczególnie w zakresie obszarów regulowanych przez prawo Unii Europejskiej, musiał zostać poddany rewizji, aby państwa nordyckie będące państwami członkowskimi UE mogły dalej w nim uczestniczyć. Warto również wspomnieć, że zgodnie ze szwedzkim porządkiem prawnym przepisy aktów prawa międzynarodowego, z wyjątkiem odpowiednich aktów prawa Unii Europejskiej, nie mogą być bezpośrednio stosowane przez szwedzkie sądy. Aby postanowienia umów międzynarodowych mogły stanowić podstawę prawną działania i rozstrzygnięć sądów, wymagają implementacji do krajowych aktów prawnych poprzez wskazanie w ich treści na bezpośrednie stosowanie norm aktu międzynarodowego bądź dostosowanie aktu krajowego w danym przedmiocie

${ }^{21}$ Z. Doliwa-Klepacki, Europejska integracja gospodarcza, Temida 2, Białystok, 1996, s. 55.

${ }^{22} \mathrm{~W}$ tym temacie, a także w kwestii postrzegania prawa obcego zob. więcej U. Maunsbach, Sweden: Proof of and Information About Foreign Law in Civil and Commercial Matters - Swedish Perspectives, in: Treatment of Foreign Law - Dynamics towards Convergence?, ed. Y. Nishitani, ,Ius Comparatum — Global Studies in Comparative Law" 2017, 26, s. 347-360.

${ }^{23}$ Zob. więcej M. Bogdan, U. Maunsbach, Private International Law in Sweden, ed. 3, Wolters Kluwer, 2020. 
do postanowień aktu międzynarodowego. Obrazującym to przykładem jest ustawa o dziedziczeniu w sytuacjach międzynarodowych ${ }^{24}$, w której treści wprowadzono m.in. reguły dotyczące dziedziczenia w sytuacjach objętych częścią zakresu nordyckiej konwencji spadkowej, gdy w danej sytuacji występuje „element nordycki”.

System szeroko pojętego szwedzkiego prawa prywatnego międzynarodowego charakteryzuje się wspomnianą wielością źródeł jego norm. Ponadto, w szwedzkiej praktyce legislacyjnej przyjęto system wdrażania norm prawa prywatnego międzynarodowego w aktach normatywnych, które nie stanowią kompleksowej regulacji tej dyscypliny prawa. Zamiast tworzenia kodyfikacji obejmującej krajowy system prawa prywatnego międzynarodowego, praktykuje się poszerzanie poszczególnych aktów prawnych zawierających merytoryczne regulacje konkretnych zagadnień bądź dziedzin prawa o przepisy wyrażające normy kolizyjne. Co więcej, źródeł norm kolizyjnych niejednokrotnie należy szukać wśród zasad niepisanych, wynikających z orzecznictwa, którego interpretacja, choć oficjalnie nie stanowi źródła prawa, jest jednak wiążąca ${ }^{25}$.

W kontekście nordyckiego modelu współpracy we wskazanym obszarze można przyjąć, że mamy do czynienia z definicją prawa prywatnego międzynarodowego $\mathrm{w}$ znaczeniu szerokim ${ }^{26}$, gdzie oprócz wyodrębnionych z aktów norm kolizyjnych znaleźć można również normy jurysdykcyjne, normy prawa materialnego oraz przepisy tworzące ramy proceduralnej współpracy między państwami. Dziedzinami, na których nordycka współpraca prawna skupiała się w największym stopniu, były prawo rodzinne, spadkowe oraz upadłościowe. W wymienionych obszarach ustanowiono kompleksowe międzynarodowe regulacje.

\subsection{Konwencja w przedmiocie upadłości (Den nordiska konventionen om konkurs)}

Konwencja nordycka o upadłości została zawarta 7 listopada $1933 \mathrm{r}$. między Danią, Szwecją, Finlandią, Norwegią i Islandią ${ }^{27}$. Naczelnym

${ }^{24} \operatorname{Lag}(2015: 417)$ om arv i internationella situationer, SFS no. 2015:417, akt dostępny na stronie: https://www.riksdagen.se/sv/dokument-lagar/dokument/svenskforfattnings samling/lag-2015417-om-arv-i-internationella_sfs-2015-417 [Dostęp: 31.08.2021 r.].

${ }^{25}$ M. Bogdan, U. Maunsbach, Private International Law...

${ }_{26}$ Zob. więcej M. Pazdan, Pojęcie prawa prywatnego międzynarodowego, w: System Prawa Prywatnego, T. 20A, Prawo prywatne międzynarodowe, red. M. Pazdan, C.H. Beck, Warszawa, 2014, s. 8-10; M. Czepelak, Umowa międzynarodowa...

${ }^{27}$ Istotne porozumienia między państwami - stronami Konwencji, zmieniające jej treść miały miejsce w roku 1977, Överenskommelse med Danmark, Finland, Island 
celem Konwencji jest zapewnienie uznawania i wykonywania decyzji $\mathrm{w}$ przedmiocie ogłoszenia upadłości ${ }^{28}$. Konwencja zawiera normy kolizyjne w kwestiach związanych z ogłoszeniem upadłości i wiążącymi się z tym skutkami, nie wskazuje jednak bezpośrednio jurysdykcji sądów. Główną zasadą wynikającą z Konwencji, w przypadku ogłoszenia upadłości w jednym z państw nordyckich, jest automatyczne uznawanie tego ogłoszenia $\mathrm{w}$ pozostałych państwach stronach co do majątku upadłego znajdującego się w tych państwach. Konwencja jednak odnosi się jedynie do upadłości ogłoszonych w państwie będącym jej stroną ${ }^{29}$. Akt wskazuje, że prawem właściwym w przedmiocie m.in. ustalenia zakresu masy upadłości, prawa i obowiązków upadłego, praw wierzycieli czy kwestii zarządzania majątkiem powinno być prawo państwa, w którym postępowanie upadłościowe zostało wszczęte, o ile nie zachodzi żaden z określonych w Konwencji wyjątków - m.in. wyłączenie z masy upadłości składników majątku, które według prawa państwa ich położenia nie podlegają egzekucji ${ }^{30}$, czy istnienie szczegółowych reguł dotyczących egzekucji nieruchomości, statków wodnych i powietrznych ${ }^{31}$. Kwestii obowiązywania i stosowania w każdym z państw sygnatariuszy poszczególnych norm Konwencji poświęcono wiele miejsca w literaturze państw nordyc-

och Norge om ändring av den nordiska konventionen den 7 november 1933 om konkurs, Köpenhamn den 11 oktober 1977 (SÖ 1978:10) oraz w roku 1982 - Överenskommelse mellan Sverige, Danmark, Finland, Island och Norge om ändring av den nordiska konventionen den 7 november 1933 om konkurs (SÖ 1934:8 och 1978:10), Köpenhamn den 11 oktober 1982 (SÖ 1982:85).

${ }^{28}$ Konwencja nie ustanawia definicji legalnej pojęcia upadłości. Kwestię tę rozstrzyga prawo materialne każdego z państw będących stronami. Postanowienia Konwencji obejmują zarówno upadłość osób fizycznych, również nieprowadzących działalności gospodarczej, jak i osób prawnych. Jej postanowienia nie obejmują szczegółowych zasad w sprawie likwidacji oraz restrukturyzacji przedsiębiorstw.

${ }^{29}$ Państwa są zobowiązane do uznania skuteczności ogłoszenia upadłości w innym państwie nordyckim, nawet jeżeli według ich własnego prawa krajowego w danej sytuacji nie zostały spełnione przesłanki uzasadniające ogłoszenie upadłości. W kwestiach administracji masą upadłości czynności podmiotu zarządzającego mogą dotyczyć wszystkich składników majątku, niezależnie od miejsca ich położenia, jeżeli znajduje się ono na terenie któregoś z państw nordyckich. Zob. więcej C. Parment, The Nordic Bankruptcy Convention - an introduction, Johann Wolfgang Goethe University Frankfurt, Frankfurt, 2004, s. 3.

${ }^{30}$ Art. 1 den nordiska konventionen den 7 november 1933 om konkurs (SÖ 1934:8), tłumaczenie pierwotnej wersji Konwencji w języku angielskim dostępne na stronie International Insolvency Institute: https://www.iiiglobal.org/sites/default/files/2-_nordic_ treaties_0.pdf [Dostęp: 31.08.2021 r.].

31 Art. 4 Överenskommelse mellan Sverige, Danmark, Finland, Island och Norge om ändring av den nordiska konventionen den 7 november 1933 om konkurs (SÖ 1934:8 och 1978:10), Köpenhamn den 11 oktober 1982 (SÖ 1982:85). 
kich $^{32}$. Wykracza ona również poza przedmiot niniejszego opracowania. Jednakże w tym miejscu należy wspomnieć o konsekwencjach związania Szwecji i Finlandii przepisami Rozporządzenia Parlamentu Europejskiego i Rady (UE) nr 2015/848 z dnia 20 maja 2015 r. w sprawie postępowania upadłościowego ${ }^{33}$.

\subsection{Konwencja o ochronie środowiska (Miljöskyddskonventionen)}

Regionalnym aktem, który został sporządzony na relatywnie wczesnym etapie umiędzynarodowienia współpracy klimatycznej, jest Konwencja o ochronie środowiska zawarta między Danią, Finlandią, Norwegią i Szwecją dnia 19 lutego 1974 r. ${ }^{34}$ Akt ten nie jest regulacją stricte z zakresu prawa prywatnego międzynarodowego, jednakże zawiera poszczególne normy, które w szerokim rozumieniu można postrzegać jako należące do tej dziedziny. Umawiające się państwa postanowiły o konieczności traktowania działań i czynników szkodliwych dla środowiska naturalnego jako spraw wspólnego zainteresowania ${ }^{35}$. Ponadto, Kon-

${ }^{32}$ Przykładem z literatury szwedzkojęzycznej może być: Ds 2007:006 Internationell insolvens - en diskussionspromemoria, Norstedts Juridik AB, 2007, s. 129, https:// books.google.pl/books?id=2BdKzvV1Z4gC\&printsec $=$ frontcover\&hl=pl\#v=onepage\&q\& $\mathrm{f}=$ false [Dostęp: 31.08.2021 r.].

${ }^{33}$ Rozporządzenie Parlamentu Europejskiego i Rady (UE) 2015/848 z dnia 20 maja 2015 r. w sprawie postępowania upadłościowego, Dz.U. L 141 z 5.06.2015, s. 19-72. Zgodnie z art. 85 Rozporządzenia nr 2015/848, zastępuje ono w swoim przedmiotowym zakresie stosowania w stosunkach pomiędzy państwami członkowskimi umowy międzynarodowe zawarte pomiędzy nimi, w tym Konwencję nordycką o upadłości. Dotyczy to postępowań wszczętych przed wejściem w życie poprzedniego rozporządzenia upadłościowego - Rozporządzenie Rady (WE) nr 1346/2000 z dnia 29 maja 2000 r. w sprawie postępowania upadłościowego, Dz.U. L 160 z 30.06.2000, s. 1-18, zastąpionego przez Rozporządzenie nr 2015/848. Konwencja nordycka będzie miała jednak zastosowanie w stosunkach między Szwecją lub Finlandią a państwami niebędącymi członkami Unii Europejskiej w zakresie, w jakim Rozporządzenie nr 2015/848 jest sprzeczne z zobowiązaniami w sprawach dotyczących upadłości wynikającymi z Konwencji nordyckiej, w postępowaniach wszczętych przed wejściem w życie Rozporządzenia nr 1346/2000.

${ }^{34}$ Miljöskyddskonventionen mellan Danmark, Finland, Norge och Sverige, Stockholm den 19 februari 1974 (SÖ 1974:99).

${ }^{35}$ Podejmowanie takich działań w jednym z państw powinno być przedmiotem debaty na poziomie międzypaństwowym, przy czym możliwe jest zawieranie porozumień między poszczególnymi państwami, dotyczących szczegółowych kwestii klimatycznych, które wyłączają stosowanie Konwencji w zakresie przez nie określonym. Kwestie działań szkodliwych dla środowiska w jednym z państw umawiających się traktowane są na równi z działaniami szkodliwymi w innym państwie. Działania szkodliwe zdefiniowane zostały m.in. jako dysponowanie odpadami, wykorzystanie ziemi oraz zasobów naturalnych czy działania zanieczyszczające powietrze. 
wencja umożliwia ubieganie się o odszkodowanie i podejmowanie innych kroków prawnych przed sądami czy organami administracyjnymi innych państw umawiających się. Jednocześnie organy sądowe, administracyjne i władze państwowe zobowiązane są do współdziałania w kwestiach ochrony środowiska, przez co rozumie się m.in. umożliwienie i usprawnienie obiegu dokumentów czy powoływanie instytucji i organów na rzecz kontroli działań szkodliwych.

\subsection{Konwencja w przedmiocie zabezpieczeń społecznych (Nordisk konvention om social trygghet)}

Aktualną wersją aktu jest Konwencja nordycka o zabezpieczeniach społecznych zawarta w Bergen 12 lipca 2012 r. ${ }^{36}$ przez Danię, Szwecję, Norwegię, Finlandię oraz Islandię, którą stworzono z myślą o uzupełnieniu regulacji międzynarodowych, w tym w ramach Europejskiego Obszaru Gospodarczego oraz Unii Europejskiej. Ideą Konwencji jest dążenie do jak najbardziej swobodnego przemieszczania się ludności między państwami nordyckimi, czemu sprzyja szeroki dostęp do świadczeń wynikających z ubezpieczeń społecznych oraz klarowne zasady dotyczące ich pozyskiwania. Podobnie jak Konwencja o ochronie środowiska, omawiany akt również nie stanowi jednolitej regulacji z zakresu prawa prywatnego międzynarodowego. Jednakże w jego treści można znaleźć pojedyncze normy kolizyjne, jak również przepisy mieszczące się w szerokim ujęciu tej dziedziny prawa. Konwencja zakreśla zasady, jakimi powinny kierować się państwa nordyckie we współpracy w omawianej dziedzinie i z którymi powinno być zgodne krajowe ustawodawstwo obejmujące kwestie zabezpieczeń społecznych. Generalną zasadą jest stosowanie Konwencji wobec sytuacji dotyczących osób zamieszkałych w jednym z państw nordyckich, a także ich rodzin. Konwencja precyzuje, że o tym, czy osoba ma miejsce zamieszkania w danym państwie nordyckim, decyduje prawo tego państwa. W razie konfliktu uważa się, że osoba ma miejsce zamieszkania w państwie, w którym jest ona zarejestrowana jako zamieszkała. Przepisy omawianego aktu określają również zasady w przypadku dostępu do ubezpieczeń społecznych z poszczególnych tytułów, ponoszenia kosztów przez państwa oraz współpracy na szczeblu administracyjnym.

${ }^{36}$ Nordisk konvention om social trygghet, Bergen den 12 juni 2012 (SÖ 2014:5). 


\section{Nordycka konwencja dotycząca spraw spadkowych (Den nordiska konventionen om arv, testamente och boutredning]}

\subsection{Geneza Konwencji}

Państwa nordyckie już w 1934 r. stwierdziły, że w celu urzeczywistnienia regionalnej współpracy na gruncie prawnym zaistniała potrzeba formalnego ujednolicenia norm kolizyjnych w zakresie prawa spadkowego. Wraz z zacieśnianiem więzi i rozwojem współpracy między państwami, a co za tym idzie migracji obywateli wewnątrz regionu, kwestie i problemy związane z tą gałęzią prawa zyskały doniosłe znaczenie, tym bardziej, że rozwiązania przyjęte przez materialne prawo spadkowe oraz reguły kolizyjne w państwach nordyckich znacznie różniły się od siebie ${ }^{37}$. Nordycka konwencja spadkowa, czyli Konwencja z dnia 19 listopada 1934 r. między Danią, Finlandią, Islandią, Norwegią i Szwecją, obejmuje przepisy prawa prywatnego międzynarodowego dotyczące dziedziczenia, testamentów i zarządzania spadkiem. Zawiera w przeważającej części normy kolizyjne stosowane w sprawach spadkowych, jak również uregulowania dotyczące jurysdykcji oraz uznawania i wykonywania orzeczeń.

Po złożeniu dokumentów ratyfikacyjnych w dniu 14 czerwca 1935 r. Konwencja weszła w życie 1 stycznia 1936 r. Akt ten na przestrzeni wielu lat obowiązywania wymagał dostosowania jego treści do zmieniającej się rzeczywistości faktycznej i prawnej. Od czasów gdy Konwencja weszła w życie, zwłaszcza po utworzeniu wspólnego nordyckiego rynku pracy w 1955 r., przepływ mieszkańców państw będących jej stronami zwiększył się w znacznym stopniu. Konwencja stworzyła praktyczne rozwiązania, przydatne dla rozwijającej się nordyckiej współpracy, która wymagała zmian w prawie krajowym państw nordyckich, obejmujących także reguły kolizyjne w sprawach międzynarodowych z zakresu spraw spadkowych $^{38}$. Ostatnie, przed 2012 r., większe poprawki miały miejsce w latach siedemdziesiątych, kiedy to zmienione zostały unormowania do-

${ }^{37}$ Zob. więcej: M. Jänterä-Jareborg, Överenskommelsen av den 1. juni 2012 om ändring av den nordiska arvskonventionen, in: Utviklingen i nordisk arvrett - tegn i tiden, Nordisk arvrettskonferanse 24. oktober 2012, TemaNord: 2013:517, 20013, s. 68.

38 Den nordiska konventionen om arv, testamente och boutredning (antagen $i$ Köpenhamn 19.11.1934) En översyn av konventionsregleringen föreslagen av den nordiska expertgruppen för familjerättsfrågor, Nordiska ministerrådet, TemaNord 2013:528, s. 27. 
tyczące formy testamentu oraz częściowo skorygowano warunki uznawania i wykonywania orzeczeń oraz decyzji w sprawach spadkowych.

Obecny kształt i brzmienie Konwencji zdeterminowane są m.in. przyjęciem przez Parlament Europejski oraz Radę Unii Europejskiej Rozporządzenia nr 650/2012 w sprawie jurysdykcji, prawa właściwego, uznawania i wykonywania orzeczeń, przyjmowania i wykonywania dokumentów urzędowych dotyczących dziedziczenia oraz w sprawie ustanowienia europejskiego poświadczenia spadkowego. Rozporządzenie to wyklucza pierwszeństwo stosowania dwustronnych bądź wielostronnych umów między państwami członkowskimi przed Rozporządzeniem, w zakresie przez nie objętym. Jednakże, za sprawą postulatów zgłoszonych przez przedstawicieli Szwecji oraz Finlandii podczas prac przygotowawczych ${ }^{39}$, w treści Rozporządzenia umożliwiono stosowanie nordyckiej Konwencji spadkowej w poniższym zakresie:

„Niniejsze rozporządzenie nie wyklucza stosowania Konwencji z dnia 19 listopada 1934 r. między Danią, Finlandią, Islandią, Norwegią i Szwecją obejmującej przepisy prawa prywatnego międzynarodowego dotyczące dziedziczenia, testamentów i zarządzania spadkiem, w wersji zmienionej porozumieniem międzyrządowym między tymi państwami z dnia 1 czerwca 2012 r. przez państwa członkowskie będące jej stronami, w zakresie, w jakim konwencja ta przewiduje:

a) przepisy dotyczące proceduralnych aspektów zarządzania spadkiem określonych $\mathrm{w}$ konwencji oraz pomocy w tym zakresie udzielanej przez organy umawiających się państw stron konwencji; oraz

b) uproszczone i szybsze procedury uznawania i wykonywania orzeczeń w sprawach spadkowych"40.

Prace nad unijnym rozporządzeniem oraz nad nowelizacją Konwencji odbywały się niemal równolegle. Państwa nordyckie zmuszone były, również pod presją czasu, obrać taki kierunek rewizji treści Konwencji, aby w pierwszej kolejności zapobiec konfliktom związanym ze stosowaniem norm Rozporządzenia w Szwecji i Finlandii, a także utrzymać dotychczasowe ramy współpracy nordyckiej na gruncie prawa prywatnego, włączając $\mathrm{w}$ to kolizyjnoprawne zagadnienia spadkowe. Rozwiązaniem, jakie przyjęto, była zmiana projektu nowelizacji Konwencji, sporządzonego jeszcze w roku 2009, oraz ukształtowanie podstawowych norm kolizyjnych dotyczących dziedziczenia i testamentu w sposób zgodny z tre-

${ }^{39}$ Den nordiska konventionen..., s. 7-11.

${ }^{40}$ Art. 75 ust. 3 Rozporządzenia Parlamentu Europejskiego i Rady (UE) nr 650/2012 z dnia 4 lipca 2012 r. w sprawie jurysdykcji, prawa właściwego, uznawania i wykonywania orzeczeń, przyjmowania i wykonywania dokumentów urzędowych dotyczących dziedziczenia oraz w sprawie ustanowienia europejskiego poświadczenia spadkowego, Dz.U. L 201 z 27.07.2012, s. 107-134. 
ścią Rozporządzenia. Pozwoliło to na stworzenie stosunkowo jednolitych reguł dotyczących wyboru prawa właściwego w najistotniejszych kwestiach w granicach Europy, włączając w to państwa nienależące do Unii Europejskiej ${ }^{41}$.

Porozumienie między Danią, Finlandią, Islandią, Norwegią i Szwecją z dnia 1 czerwca 2012 r. zmieniło treść Konwencji w sposób znaczący. Brzmienie większości artykułów zostało zaktualizowane, dodano dwa nowe artykuły - art. 3a oraz art. 3b, a także uchylono kilka uregulowań. Porozumienie to w rzeczywistości zastępuje dotychczasową treść Konwencji, będąc nową umową międzynarodową, do której państwa przystępowały, podpisując ją wraz z zastrzeżeniem późniejszej ratyfikacji lub zatwierdzenia, bądź bez niego ${ }^{42}$.

\subsection{Ogólna charakterystyka Konwencji}

Struktura Konwencji obejmuje art. 1-30, dzielące się na cztery główne części, zawierające następujące zagadnienia:

1) art. 1-16 - Prawo właściwe w sprawach dziedziczenia i testamentu,

2) art. 17-18 - Prawo właściwe w kwestiach długów testamentowych,

3) art. 19-26 - Jurysdykcja i prawo właściwe dla kwestii podziału majątku spadkowego oraz zarządu spadkiem,

4) art. 27-30 - Postanowienia ogólne, uznawanie i wykonywanie orzeczeń.

Zakres temporalny zastosowania Konwencji ograniczony jest do sytuacji, gdy spadkodawca lub małżonek pozostający przy życiu w chwili śmierci spadkodawcy, który przejął majątek spadkowy, zmarł najwcześniej w dniu wejścia w życie Konwencji, a po 2012 r. - w dniu wejścia w życie wspomnianego Porozumienia, które miało miejsce 1 września 2015 r.

Akt ten obowiązuje na terenie państw do niego przystępujących Danii, Islandii, Norwegii, Szwecji i Finlandii. W treści aktu znaleźć można jednak przepis, zgodnie z którym terytoria autonomiczne - Wyspy Owcze i Grenlandia, nie przystępują do Porozumienia, z zastrzeżeniem, że może ono zostać tam wprowadzone w życie $\mathrm{z}$ odpowiednimi zmianami po negocjacjach między duńskim ministerstwem sprawiedliwości a właściwymi ministerstwami pozostałych umawiających się państw.

${ }^{41}$ Den nordiska konventionen..., s. 30-31.

42 Överenskommelse med Danmark, Finland, Island och Norge om ändring av konventionen med Finland, Danmark, Island och Norge undertecknad i Köpenhamn den 19 november 1934 (SÖ 1935:17), om arv, testamente och boutredning Köpenhamn den 1 juni 2012 (SÖ 2015:1). 
Konwencja obejmuje w głównej mierze sytuacje, gdy zmarły był obywatelem jednego z państw nordyckich oraz posiadał miejsce zwykłego pobytu (szw. hemvist ${ }^{43}$ ) w innym państwie nordyckim w momencie śmierci. Istnieją jednak wyjątki pozwalające na stosowanie postanowień aktu również w sytuacji, gdy zmarły posiadał miejsce zwykłego pobytu w państwie, którego był obywatelem ${ }^{44}$. W czasie opracowywania Konwencji zasada obywatelstwa była ugruntowana zarówno w orzecznictwie fińskim, jak i szwedzkim w sprawach spadkowych z elementem międzynarodowym, podczas gdy w pozostałych państwach stosowano zasadę domicylu, a następnie zwykłego pobytu. Rozwiązanie przyjęte przez Konwencję stanowi więc swoisty kompromis, pozwalający na dostosowanie jej do prawa krajowego w sposób uniwersalny ${ }^{45}$.

Zasada ogólna, wynikająca przede wszystkim z art. 2 Konwencji, stanowi, że prawem właściwym w kwestii prawa do dziedziczenia po zmarłym jest prawo tego państwa umawiającego się, w którym miał on miejsce zwykłego pobytu w chwili śmierci ${ }^{46}$. Wyjątkiem od owej zasady jest stosowanie lex rei sitae w stosunku do nieruchomości wchodzącej w skład spadku, co uregulowane zostało w art. 13 Konwencji ${ }^{47}$. Wraz z nowe-

${ }^{43}$ Konwencja nie definiuje pojęcia hemvist. Jednakże można przyjąć, że oznacza ono zwykły pobyt w rozumieniu m.in. prawodawstwa unijnego w zakresie aktów prawa prywatnego międzynarodowego i międzynarodowego postępowania cywilnego. Zob. więcej M. Jänterä-Jareborg, Överenskommelsen av den 1. juni 2012 om ändring av den nordiska arvskonventionen, in: Utviklingen $i$ nordisk arvrett - tegn $i$ tiden, Nordisk arvrettskonferanse 24. oktober 2012, TemaNord: 2013:517, 2013, s. 83; por. M. Jänterä-Jareborg, Behövs det särskilda internordiska regler om makars egendomsförhållanden och arv?, in: Bonus pater familias: festskrift til Peter Lødrup 70 år, 2002, s. 3.

${ }^{44}$ Art. 1 Konwencji:

„Postanowienia niniejszej konwencji dotyczą kwestii dziedziczenia oraz testamentu po osobie, która w momencie śmierci była obywatelem i miała miejsce zwykłego pobytu w jednym z umawiających się państw, chyba że co innego wynika z rozporządzenia Parlamentu Europejskiego i Rady (UE) w sprawie jurysdykcji, prawa właściwego, uznawania i wykonywania orzeczeń, przyjmowania i wykonywania dokumentów urzędowych dotyczących dziedziczenia oraz w sprawie ustanowienia europejskiego poświadczenia spadkowego". Tłum. J. Klimala.

${ }^{45}$ Den nordiska konventionen..., s. 11-12.

${ }^{46}$ Art. 2 Konwencji:

„Gdy spadkodawca nie zdecydował inaczej w stosunku do tego, co wynika z artykułu 3, prawem właściwym w kwestii prawa do dziedziczenia po nim jest prawo tego państwa umawiającego się, w którym miał on miejsce zwykłego pobytu w chwili śmierci.

Jeżeli, w drodze wyjątku, ze wszystkich okoliczności sprawy wynika, że zmarły w chwili śmierci był wyraźnie ściślej związany z innym umawiającym się państwem niż to, którego prawo miałoby zastosowanie na podstawie poprzedniego ustępu, prawo tego państwa stosuje się w odniesieniu do prawa do dziedziczenia”. Tłum. J. Klimala.

${ }^{47}$ Art. 13 Konwencji:

„Dla kwestii dotyczących nieruchomości stosuje się szczególne reguły obowiązujące w państwie jej położenia, dotyczące prawa spadkobiercy do nieruchomości wraz z przy- 
lizacją Konwencji przestała obowiązywać zasada tzw. femårsregeln (szw.), zgodnie z którą łącznik zwykłego pobytu stosowany mógł być dopiero wówczas, gdy zwykły pobyt spadkodawcy przed śmiercią w danym państwie trwał co najmniej pięć lat. W przeciwnym razie stosowany był łącznik obywatelstwa. Rozwiązanie to wpływało ograniczająco na swobodne przemieszczanie się oraz integrację wewnątrz rejonu nordyckiego $0^{48}$.

Artykuł 2 Konwencji wprowadza również klauzulę ściślejszego związ$\mathrm{ku}$, mającą zastosowanie w sytuacjach wyjątkowych. Zgodnie z tą zasadą, w sprawach dotyczących prawa do dziedziczenia, biorąc pod uwage wszystkie ich okoliczności, stosować należy prawo tego innego państwa umawiającego się, z którym spadkodawca był wyraźnie silniej związany.

Kolejny artykuł (art. 3) umożliwia spadkodawcy dokonanie wyboru prawa $^{49}$. Wybór ten jest jednak ograniczony do prawa wskazanego łącznikiem obywatelstwa. Spadkodawca może dokonać wyboru prawa tego państwa umawiającego się, którego jest obywatelem w momencie dokonywania tego wyboru bądź w chwili śmierci. Wybór prawa jest możliwy również wtedy, gdy spadkodawca posiada obywatelstwo więcej niż jednego państwa strony Konwencji. Jeżeli spadkodawca dokona wyboru prawa innego niż prawo państwa umawiającego się, ważność tego wyboru będzie oceniana na podstawie przepisów tego państwa umawiającego się, w którym wyboru dokonano.

Wymienione artykuły zarysowują ogólny system wewnątrz Konwencji, zgodnie z którym w celu wskazania prawa właściwego dla oceny pra-

należnościami bądź prawa spadkodawcy do rozrządzenia daną nieruchomością w testamencie na rzecz niektórych spadkobierców.

Prawo do uczynienia w testamencie zapisu powierniczego dotyczącego nieruchomości bądź innego rozrządzenia nieruchomością na rzecz nienarodzonego dziecka jest oceniane zgodnie z prawem państwa, w którym nieruchomość się znajduje. Niniejsza konwencja nie ma zastosowania do dokonania tego rodzaju rozrządzeń, które nie dotyczą nieruchomości”. Tłum. J. Klimala.

${ }^{48}$ M. Jänterä-Jareborg, Överenskommelsen av den 1. juni 2012 om ändring av den nordiska arvskonventionen, in: Utviklingen $i$ nordisk arvrett - tegn $i$ tiden, Nordisk arvrettskonferanse 24. oktober 2012, TemaNord: 2013:517, 2013, s. 69.

${ }^{49}$ Art. 3 Konwencji:

„Spadkodawca może zdecydować, że prawo do dziedziczenia po nim będzie podlegało prawu tego państwa umawiającego się, którego w momencie wyboru prawa bądź śmierci jest obywatelem.

Spadkodawca, który jest obywatelem kilku państw umawiających się, może wybrać prawo jednego z tych państw, których był obywatelem w czasie wyboru prawa bądź śmierci.

Jeśli spadkodawca zdecydował, że prawem właściwym ma być prawo państwa niebędącego stroną konwencji, ważność wyboru prawa będzie oceniana, w każdym z państw umawiających się, na podstawie ogólnych zasad tamże obowiązujących”. Tłum. J. Klimala. 
wa do dziedziczenia w pierwszej kolejności powinien być brany pod uwagę wybór prawa dokonany przez spadkodawcę zgodnie z wyżej wskazanymi regułami. W razie braku wyboru prawa stosowany jest łącznik ostatniego miejsca zwykłego pobytu osoby zmarłej. Miejsce to powinno jednak przypadać na terytorium jednego z państw umawiających się, a z ogółu okoliczności sprawy nie wynika, że spadkodawca był ściślej związany $\mathrm{z}$ innym państwem stroną.

Znaczna część Konwencji poświęcona jest kwestiom ważności formalnej podejmowanych przez spadkodawcę czynności. Ustanowione Porozumieniem z 2012 r. art. 3a i 3b odnoszą się do formy wymaganej dla dokonania wyboru prawa właściwego. Czynność ta powinna zostać dokonana w formie, która wymagana jest dla ważności testamentu. Wybór prawa właściwego może być również wyrażony jako postanowienie w testamencie. Ważność odwołania wyboru prawa uzależniona jest od jego dokonania w formie wymaganej dla odwołania testamentu. Jednocześnie w tym miejscu Konwencja odwołuje się do art. 8, który wyznacza zasady wymagane dla formy ustanowienia testamentu. Zgodnie $\mathrm{z}$ tym przepisem, ważność testamentu pod względem formy oceniana jest według prawa państwa, w którym testament został ustanowiony, lub prawa państwa, w którym spadkodawca w momencie ustanawiania testamentu bądź śmierci miał miejsce zwykłego pobytu, albo którego był obywatelem. Na tej samej zasadzie oceniana jest ważność odwołania lub zmiany testamentu. W kwestii rozrządzeń testamentowych obejmujących nieruchomość ważność testamentu pod względem formy oceniana będzie na podstawie prawa tego państwa, w którym nieruchomość się znajduje. Artykuł 8 wprowadza również, nieczęste w treści Konwencji, odejście od zasady zwykłego pobytu na rzecz domicylu dla oceny ważności testamentu bądź jego odwołania czy zmiany pod względem formy ${ }^{50}$.

50 Art. 8 Konwencji:

„Ważność testamentu pod względem formy oceniana jest według prawa państwa, w którym testament został ustanowiony, lub państwa, w którym spadkodawca w momencie ustanawiania testamentu bądź śmierci miał miejsce zwykłego pobytu, albo którego był obywatelem.

Jeżeli testament obejmuje nieruchomość, jego ważność pod względem formy oceniana będzie również na podstawie prawa państwa, w którym nieruchomość się znajduje.

Pierwszy akapit ma odpowiednie zastosowanie w przypadku zmiany lub odwołania testamentu. Odwołanie również uznaje się za ważne pod względem formy, jeśli spełnia wymogi przepisów prawa, zgodnie z którym tenże odwołany testament, na podstawie akapitu pierwszego, jest ważny pod względem formy.

Jeśli testator, według prawa państwa niebędącego stroną konwencji, miał miejsce zamieszkania $\mathrm{w}$ tym państwie, dla kwestii poruszonych $\mathrm{w}$ pierwszym i drugim akapicie, zamiast miejsca zwykłego pobytu, można zastosować łącznik miejsca zamieszkania. 
Zgodnie z art. 9 Konwencji ${ }^{51}$, ocena zdolności spadkodawcy do ustanowienia bądź odwołania testamentu powinna być dokonana według prawa właściwego wskazanego przez ogólną zasadę wynikającą z art. 2 i 3. Spadkodawca zostanie jednak uznany za zdolnego do ustanowienia lub odwołania testamentu, jeśli posiadał ową zdolność według prawa państwa zwykłego pobytu, będącego jednocześnie państwem stroną Konwencji w momencie dokonywania czynności. Jednakże gdyby zwykły pobyt nie miał miejsca $\mathrm{w}$ państwie umawiającym się, to zastosowanie ma wspomniana reguła, wskazująca na krajowe systemy prawne poszczególnych umawiających się państw. Zasada ta została również włączona do kolejnych artykułów Konwencji, dotyczących podważenia testamentu, umowy dziedziczenia i darowizny na wypadek śmierci.

Artykuł 10 Konwencji dotyczy podważenia ważności ustanowienia testamentu bądź jego odwołania ze względu na stan psychiczny spadkodawcy lub z powodu oszustwa, błędu, przymusu czy innego bezprawnego zewnętrznego wpływu. W sytuacji tej wskazano, że prawem właściwym powinno być prawo państwa, w którym spadkodawca miał miejsce zwykłego pobytu w czasie, gdy bezprawny czyn lub stan psychiczny wpływający na ważność ustanowienia testamentu miał miejsce.

Powyższe regulacje dotyczące kwestionowania ważności testamentu, tj. art. 8-10, nie znajdą jednak zastosowania, gdy spadkodawca w chwili śmierci miał miejsce zwykłego pobytu w Szwecji lub Finlandii, gdyż $\mathrm{w}$ takim przypadku stosowane jest prawo obowiązujące $\mathrm{w}$ tych państwach. Ma to związek przede wszystkim ze związaniem tych państw przepisami unijnego rozporządzenia spadkowego. Również na rzecz Norwegii wprowadzone zostało dodatkowe ograniczenie. Przepisy prawa norweskiego, zgodnie z którymi prawa wynikające z treści testamentu oraz sprzeciw wobec ważności testamentu są ograniczone określonym terminem, stosuje się także w przypadku testamentu obywatela in-

Do innych niż poruszone w akapicie pierwszym, drugim lub trzecim kwestii dotyczących stosowania prawa państwa niebędącego państwem umawiającym się zastosowanie mają zasady ogólne obowiązujące w każdym umawiającym się państwie”. Tłum. J. Klimala.

51 Art. 9 Konwencji:

„W kwestii oceny zdolności spadkodawcy do ustanowienia bądź odwołania testamentu prawem właściwym jest prawo tego państwa umawiającego się, którego prawo jest właściwe wg artykułu 2 lub 3 w kwestii prawa do dziedziczenia po zmarłym.

Uważa się również, że spadkodawca jest zdolny do sporządzenia lub odwołania testamentu, jeżeli posiadał takie uprawnienia na mocy prawa umawiającego się państwa, w którym miał miejsce zwykłego pobytu w chwili ustanowienia lub odwołania.

Jeżeli spadkodawca w danym czasie miał miejsce zwykłego pobytu w państwie niebędącym umawiającym się państwem, zastosowanie mają ogólne zasady obowiązujące w każdym umawiającym się państwie”. Tłum. J. Klimala. 
nego umawiającego się państwa, jeżeli w chwili śmierci miał on miejsce zwykłego pobytu w Norwegii. Opisane wyjątki wynikają z art. 11 Konwencji.

W treści art. 12 poruszono natomiast problematykę umów dotyczących spadku, darowizn mortis causa, a także majątku otrzymanego przez spadkobiercę od spadkodawcy podlegającego zaliczeniu na poczet spadku, których wiążący skutek ocenia się na podstawie prawa państwa, które następnie zgodnie z art. 2 lub 3 stosuje się do prawa do dziedziczenia. Regulacja ta pozwala więc na pośredni wybór prawa oraz, w pewnym stopniu, wzmocnienie gwarancji, że wola spadkodawcy zostanie wypełniona, kwestie te bowiem w prawie materialnym poszczególnych państw uregulowane mogą być odmiennie.

W dalszej kolejności Konwencja porusza wspomnianą wcześniej kwestię dziedziczenia nieruchomości ${ }^{52}$, a także problem dziedziczenia przy stosunku przysposobienia ${ }^{53}$, zagadnienie upływu terminu do przyjęcia spadku ${ }^{54}$ oraz kwestię pasywów spadku ${ }^{55}$.

${ }^{52}$ Art. 13 Konwencji:

„Dla kwestii dotyczących nieruchomości stosuje się szczególne reguły obowiązujące w państwie jej położenia, dotyczące prawa spadkobiercy do nieruchomości wraz z przynależnościami bądź prawa spadkodawcy do rozrządzenia daną nieruchomością w testamencie na rzecz niektórych spadkobierców.

Prawo do uczynienia $\mathrm{w}$ testamencie zapisu powierniczego dotyczącego nieruchomości bądź innego rozrządzenia nieruchomością na rzecz nienarodzonego dziecka jest oceniane zgodnie z prawem państwa, w którym nieruchomość się znajduje. Niniejsza konwencja nie ma zastosowania do dokonania tego rodzaju rozrządzeń, które nie dotyczą nieruchomości”. Tłum. J. Klimala.

${ }^{53}$ Podczas prac przygotowawczych do Porozumienia zmieniającego Konwencję twórcy zdecydowali, że utrzymanie art. $14 \mathrm{w}$ dotychczasowym brzmieniu wydaje się celowe, z tego względu, że odnosi się on do odrębności, mających zastosowanie głównie w prawie duńskim, dotyczących zastrzeżeń przy ustanowieniu stosunku przysposobienia, które powinny być stosowane również w innych państwach umawiających się, jeżeli adoptowane dziecko jest obywatelem jednego z tych państw. Zob. więcej Den nordiska konventionen..., s. 53; Art. 14 Konwencji:

„Jeśli adoptowane dziecko jest obywatelem jednego z umawiających się państw, a zezwolenie na adopcję udzielane jest $\mathrm{w}$ jednym $\mathrm{z}$ tych państw, $\mathrm{z}$ zastrzeżeniem adoptującego do rozrządzenia majątkiem spadkowym bez uszczerbku dla adopcji, zastrzeżenie to powinno mieć zastosowanie również w pozostałych państwach”. Tłum. J. Klimala.

${ }^{54}$ Art. 16 Konwencji:

„Dla kwestii przedawnienia prawa/upływu terminu do przyjęcia spadku bądź testamentu po spadkodawcy prawem właściwym będzie prawo ustalone na podstawie artykułu 2 bądź 3 dla prawa do dziedziczenia”. Tłum. J. Klimala.

55 Art. 17 Konwencji:

„Odpowiedzialność spadkobiercy za zobowiązania spadkodawcy będącego obywatelem jednego z umawiających się państw, długi spadkowe bądź wykonania poleceń testamentowych oceniana jest na podstawie prawa tego umawiającego się państwa, w którym spadkodawca miał miejsce zwykłego pobytu w chwili śmierci”. Tłum. J. Klimala. 
Konwencja w znacznym stopniu skupia się na regulacjach dotyczących administracji spadkiem oraz wszelkich kwestiach $\mathrm{z}$ nią powiązanych. Dostosowanie, w omawianym zakresie, postanowień Konwencji do zmian legislacyjnych, jakie nastąpiły w prawie państw nordyckich od wejścia w życie aktu, nastręczyło grupie eksperckiej opracowującej nowelizację z 2012 r. znacznych trudności. Zwrócono uwagę, że przy kolejnej rewizji Konwencji szczególną uwagę należy poświęcić tym właśnie zagadnieniom $^{56}$.

Artykuł 19 wyznacza ogólne ramy dla wskazania prawa właściwego $\mathrm{w}$ zakresie wspomnianych wyżej materii oraz jest pierwszym przepisem Konwencji odnoszącym się także do jurysdykcji ${ }^{57}$. W szwedzkojęzycznym brzmieniu wymienione zostały kwestie, które można tłumaczyć jako zarząd spadkiem, podział majątku spadkowego oraz dział spadku (boutredning, bodelning, och arvskifte), natomiast przykładowo w wersji norweskiej określone zostały one jako zarząd spadkiem i podział majątku spadkowego między spadkobierców a pozostającego przy życiu małżonka (behandlingen av et dødsbo og skifte mellom den avdødes arvinger og en gjenlevende ektefelle $\left.{ }^{58}\right)$. Na potrzeby dalszego przedstawienia cha-

\section{Art. 18 Konwencji:}

„Wezwanie nieznanych wierzycieli, które ma miejsce po otwarciu spadku, jeśli roszczenie było znane, a wierzyciel miał miejsce zwykłego pobytu w innym umawiającym się państwie, uważa się za bezskuteczne, jeżeli wierzyciel nie został powiadomiony o wezwaniu we właściwym czasie lub w inny sposób nie dowiedział się o nim”. Tłum. J. Klimala.

${ }^{56}$ Den nordiska konventionen..., s. 55.

${ }^{57}$ Art. 19 Konwencji:

„Dla kwestii zarządu spadkiem, podziału majątku spadkowego oraz działu spadku po obywatelu jednego z umawiających się państw stosuje się prawo tego państwa, w którym spadkodawca miał miejsce zwykłego pobytu w chwili śmierci. Jeśli, według tego prawa, czynności te odbywać się mają przy pomocy sądu bądź innego organu, jurysdykcja przypada sądom bądź organom państwa, którego prawo jest właściwe.

Jeżeli pozostały przy życiu małżonek, będący obywatelem jednego z umawiających się państw, przejął całość majątku spadkowego po śmierci spadkodawcy i majątek ten ma zostać podzielony między spadkobierców, stosuje się prawo tego państwa, w którym małżonek ten ma w czasie podziału bądź miał w chwili śmierci miejsce zwykłego pobytu. Jeśli według tego prawa czynność ta dokonywana jest przez sąd, jurysdykcja przypada sądom tego państwa.

Zarząd masą spadkową, podział majątku spadkowego oraz dział spadku mogą obejmować również składniki majątku spadkowego znajdujące się w innym umawiającym się państwie”. Tłum. J. Klimala.

58 Szczególne trudności w przekładzie wiążą się z terminem arvskifte. Pojęcie to tłumaczone jest m.in. jako sukcesja - art. 30 i Rozporządzenie nr 650/2012, bądź zdarzenie prawne lub procedura zbliżona do działu spadku, podczas której spadkobiercy nabywają prawa ze spadku — Kap. $23 \S 1$ Ärvdabalk (1958:637). W tłumaczeniu angielskim również distribution of an estate, według Svensk/engelsk ordlista för Sveriges Domstolar, Avdelningen för kompetensutveckling och internationella relationer och Kommunikationavdelningen, Domstolsverket, 2019. 
rakterystyki omawianej Konwencji można przyjąć, że kwestie te należy zbiorowo ująć jako problemy dotyczące zarządu spadkiem, na który składa się także podział majątku spadkowego w sensie materialnoprawnym oraz proceduralnym. Dla owych zagadnień łącznikiem wskazującym prawo właściwe jest miejsce zwykłego pobytu spadkodawcy w chwili śmierci. Przepis ten wprowadza również zasadę, zgodnie z którą, jeżeli kwestie te wiążą się ze zdarzeniami prawnymi bądź czynnościami, które według właściwego prawa mają być podejmowanie przez sądy lub inne organy, jurysdykcja przysługuje sądom i organom państwa prawa właściwego. Czynności te mogą obejmować także składniki majątku spadkowego znajdujące się w innym umawiającym się państwie. Kolejnym przepisem zawierającym normy jurysdykcyjne jest art. $21^{59}$, zgodnie z którym zasady stosowane przy wyznaczeniu jurysdykcji krajowej według art. 19 mają mieć zastosowanie również w stosunku do określenia jurysdykcji w sporach dotyczących dziedziczenia, testamentu oraz praw i roszczeń pozostającego przy życiu małżonka spadkodawcy. Przepis ten, w przypadku zgodnej woli stron, umożliwia odstępstwa od wskazanej zasady.

Znaczna część trzeciego działu Konwencji poświęcona została kwestiom praw pozostałego przy życiu małżonka spadkobiercy do udziału w majątku spadkowym oraz jego praw z tym związanych. Materia ta wymagała szczegółowej regulacji ze względu na specyficzne unormowania dla materialnego prawa spadkowego, a także procedur związanych z dziedziczeniem oraz zarządem spadkiem w poszczególnych państwach ${ }^{60}$. Między innymi w treści art. 19 i 20 wskazano, że prawem właściwym dla podziału majątku spadkowego przejętego po śmierci spadkodawcy przez jego pozostającego przy życiu małżonka, będącego obywatelem jednego z umawiających się państw, jest prawo państwa zwykłego pobytu owego małżonka zarówno w chwili podziału, jak i jego śmierci — gdy majątek dzielony

${ }^{59}$ Art. 21 Konwencji:

„Spory dotyczące dziedziczenia lub testamentu po obywatelu umawiającego się państwa, który miał miejsce zwykłego pobytu w tym Państwie, oraz kwestii praw i roszczeń co do spadku przysługujących pozostałemu przy życiu małżonkowi spadkodawcy będą rozstrzygane przez sądy tego państwa, którego prawo, zgodnie z artykułem 19, stosuje się do kwestii zarządu spadkiem, podziału majątku spadkowego i działu spadku.

Jeżeli strony wyrażą na to zgodę, spór może zostać rozstrzygnięty w innym umawiającym się państwie, z wyjątkiem przypadków, gdy spadek podlega rozpatrzeniu przez sąd, wykonawcę testamentu lub inne instytucje, albo spór dotyczy roszczeń związanych z sukcesją lub testamentem po zmarłym, który miał miejsce zwykłego pobytu w Finlandii lub Szwecji, lub kwestii podziału majątku spadkowego i działu spadku po osobie, która miała miejsce zwykłego pobytu w Finlandii”. Tłum. J. Klimala.

${ }^{60}$ M. Jänterä-Jareborg, Överenskommelsen av den 1. juni 2012..., s. 68. 
jest po śmierci tego małżonka. Reguła ma zastosowanie również wtedy, gdy małżonkowi mają zostać przekazane poszczególne składniki majątku spadkowego ${ }^{61}$.

Konwencja w szerokim zakresie obejmuje zagadnienia związane z zabezpieczeniem majątku spadkowego. Artykuł 22 wskazuje możliwości związane $\mathrm{z}$ rejestracją i tymczasowym zabezpieczeniem lub sprzedażą składników majątku spadkowego w przypadku niemożności należytego ich zabezpieczenia, jeżeli znajdują się w innym państwie, niż to, którego prawo jest właściwe na podstawie łącznika zwykłego pobytu ${ }^{62}$. Kolejne artykuły, tj. art. 23-26, wprowadzają m.in. zasadę ochrony majątku spadkowego do czasu jego podziału ${ }^{63}$, wyłączają wymóg rejestracji prawa własności wymaganej w niektórych państwach dla ważności i skutecz-

${ }^{61}$ Art. 20 Konwencji:

„Przy podziale majątku spadkowego, o którym mowa w artykule 19, w kwestii prawa pozostałego przy życiu małżonka do otrzymania, za wynagrodzeniem bądź bez, składników majątku spadkowego stosuje się prawo właściwe określone w artykule 19.

To samo dotyczy kwestii, czy małżonek posiada roszczenie, ażeby spadkobierca pozostawił mu, do korzystania bądź w posiadaniu, składnik majątku, który przypadł temu spadkobiercy w dziale spadku, a także kwestii przysługiwania spadkobiercy zastawu bądź hipoteki na tymże składniku majątku. Jednakże zastaw bądź hipoteka na majątku znajdującym się w innym umawiającym się państwie nie może powstać inaczej, niż zgodnie z prawem tego państwa”. Tłum. J. Klimala.

62 Art. 22 Konwencji:

„Jeżeli w innym państwie niż państwo, którego prawo jest właściwe ze względu na miejsce zwykłego pobytu, znajdują się przedmioty majątku należące do spadku, sądy państwa, w którym znajduje się składnik majątku, na żądanie zarządzą rejestrację i tymczasowe jego zabezpieczenie oraz sprzedaż składników majątku, które nie są odpowiednio przechowywane/zabezpieczone. Ponadto, władze tego państwa, na wniosek, udzielają pomocy $\mathrm{w}$ zabezpieczeniu mieszkania w zakresie wymaganym przez prawo tego państwa. Wniosek może zostać niezwłocznie skierowany do właściwego organu. $\mathrm{W}$ razie potrzeby koszty można uiścić z góry.

Pismom w języku fińskim lub islandzkim musi towarzyszyć uwierzytelnione tłumaczenie na język duński, norweski lub szwedzki. Jeżeli śmierć nastąpiła w innym państwie niż to, w którym zmarły miał miejsce zwykłego pobytu, majątek pozostały powinien zostać zatrzymany i zabezpieczony bez wniosku, zgodnie z obowiązującymi tam przepisami”. Tłum. J. Klimala.

${ }^{63}$ Art. 23 Konwencji:

„Jeżeli majątek, o którym mowa w artykule 19, podlega administrowaniu przez zarządce majątku spadkowego w Danii lub publicznemu podziałowi w Islandii, lub Norwegii, ograniczenia w prawie wierzyciela do zaspokojenia się z majątku spadkowego będą miały zastosowanie $\mathrm{w}$ równym stopniu do majątku w innym umawiającym się państwie.

Nie ma to jednak zastosowania w kwestii należności podatkowych lub innych opłat ogólnych nałożonych w tym państwie, a także windykacji wierzytelności z majątku, która stanowi zabezpieczenie roszczenia lub może być utrzymywana jako zabezpieczenie roszczenia”. Tłum. J. Klimala. 
ności tego prawa, jeżeli przedmioty majątku spadkowego nie znajdują się w państwie, w którym zasady takie nie obowiązują ${ }^{64}$, oraz ustanawiają zasadę, zgodnie z którą w zakresie, w jakim zastosowanie przepisów Konwencji zależy od położenia majątku, roszczenie spadkobiercy uważane jest za istniejące w państwie, którego prawo zostało wskazane jako właściwe w art. 19 dla spraw zarządu spadkiem ${ }^{65}$.

Zagadnienie uznawania i wykonywania orzeczeń porusza art. $27^{66}$. Jednocześnie otwiera on ostatnią, czwartą już, część Konwencji. Decyzje i orzeczenia sądów państw umawiających się obejmujące postanowienia dotyczące zarządu spadkiem oraz podziału majątku spadkowego obowiązują również $\mathrm{w}$ pozostałych państwach będących stronami Konwencji. Dopełnienie tej zasady stanowi brzmienie art. 28 , zgodnie z którym uznanie i wykonanie orzeczeń, a także wywołujących skutki prawne ugód ma odbywać się na podstawie prawa tego państwa, w którym uznanie i wykonanie orzeczenia ma miejsce, jeżeli dotyczy ono kwestii prawa do dziedziczenia, praw pozostającego przy życiu małżonka, podziału majątku spadkowego i odpowiedzialności spadkobiercy ${ }^{67}$.

${ }^{64}$ Art. 25 Konwencji:

„Przepisy jednego z państw, w których rejestracja własności jest niezbędna do tego, aby prawa nabyte w drodze postępowania sądowego lub przez tytuł egzekucyjny, lub w drodze praw z zastawu były ważne w stosunku do spadku, nie mają zastosowania do przedmiotów znajdujących się w chwili śmierci w innych państwach”. Tłum. J. Klimala.

${ }^{65}$ Art. 26 Konwencji:

„W zakresie, w jakim zastosowanie powyższych przepisów zależy od położenia majątku, roszczenie spadkobiercy uważane jest za istniejące w państwie, którego prawo na podstawie artykułu 19 określa sposób traktowania spadku. Jeżeli jednak roszczenie jest powiązane $\mathrm{z}$ wekslem lub innym dokumentem, którego dowód jest niezbędny do jego realizacji, uznaje się za istniejące w tym państwie, w którym dokument się znajduje.

Za miejsce położenia zarejestrowanego statku wodnego bądź powietrznego uznaje się miejsce pochodzenia bądź rejestracji”. Tłum. J. Klimala.

${ }^{66}$ Art. 27 Konwencji:

„Jeżeli sąd w umawiającym się państwie zdecyduje, że majątek, o którym mowa w artykule 19, trafi pod zarząd sądu, sądu spadkowego, zarządcy majątku spadkowego, powiernika lub wykonawcy testamentu, lub że majątek będzie przedmiotem podziału przez współuprawnionych lub zostanie podzielony pod nadzorem osoby do tego wyznaczonej, decyzja ta obowiązuje również w innych umawiających się państwach”. Tłum. J. Klimala.

${ }^{67}$ Art. 28 Konwencji:

„Prawo państwa, w którym ma nastąpić uznanie lub wykonanie orzeczenia, stosuje się do uznawania i wykonywania orzeczeń i ugód dotyczących prawa do dziedziczenia, praw pozostającego przy życiu małżonka, podziału majątku spadkowego i odpowiedzialności spadkobiercy". Tłum. J. Klimala. 
Konwencję kończą art. $29^{68}$, ustalający wspomniany już zakres temporalny obowiązywania Konwencji, oraz art. $30^{69}$, ustalający termin wejścia w życie Konwencji oraz umożliwiający wypowiedzenie tej umowy międzynarodowej przez każde z państw umawiających się wobec każdego z pozostałych państw.

\subsection{Wybrane zagadnienia szczegółowe}

\subsubsection{Rozumienie sprawy spadkowej}

Interesującym zagadnieniem, jakie pojawia się już na pierwszym etapie analizy treści Konwencji, jest rozumienie sprawy spadkowej. Konwencja potocznie określana jest jako den nordiska arvskonventionen, co tłumaczyć można jako „nordycka konwencja spadkowa” bądź „nordycka konwencja o dziedziczeniu"70.

Postanowienia Konwencji lakonicznie wyznaczają jej zakres przedmiotowy, określony jako kwestie dziedziczenia i spadku. Natomiast w większości artykułów zawierających normy kolizyjne, włączając art. 2 i 3 ustanawiające główne zasady co do wskazania prawa właściwego, operuje ona pojęciem prawa do dziedziczenia - rätt till arv (szw.). Pomijając kwestie zarządu spadkiem oraz inne szczegółowe zasady, w dalszej części aktu, przy przyjęciu wykładni literalnej, zakres przed-

${ }^{68}$ Art. 29 Konwencji:

„Postanowienia niniejszej konwencji nie mają zastosowania, jeżeli spadkodawca zmarł przed wejściem w życie konwencji, ani w przypadku, gdy pozostały przy życiu małżonek przejął całość majątku spadkowego po śmierci spadkodawcy, a pierwszy zmarły małżonek zmarł przed tą datą". Tłum. J. Klimala.

${ }^{69}$ Art. 30 Konwencji:

„Konwencja zostanie ratyfikowana, a dokumenty ratyfikacyjne będą przechowywane w archiwum Duńskiego Ministerstwa Spraw Zewnętrznych niezwłocznie.

Konwencja wejdzie w życie między państwami umawiającymi się 1 stycznia lub 1 lipca, co nastąpi po upływie trzech miesięcy od złożenia przez co najmniej trzy państwa dokumentów ratyfikacyjnych. W odniesieniu do późniejszych państw ratyfikujących konwencja wejdzie w życie 1 stycznia lub 1 lipca, co nastąpi po upływie trzech miesięcy od złożenia dokumentu ratyfikacyjnego.

Każde państwo może, w stosunku do każdego z pozostałych, wypowiedzieć konwencję z zachowaniem okresu jednego roku do następnego 1 stycznia bądź 1 lipca”. Tłum. J. Klimala.

${ }^{70}$ Termin arv odpowiada w języku polskim pojęciu dziedziczenia - sukcesji, gdyż oznacza zdarzenie przejścia praw bądź majątku ze zmarłego na spadkobiercę. Jednakże określenie „nordycka konwencja spadkowa” wydaje się tłumaczeniem poprawnym, ze względu na objęcie zakresem przedmiotowym aktu większej ilości zagadnień aniżeli jedynie dziedziczenia. 
miotowy głównych norm kolizyjnych wydaje się zawężony. Wskazane na podstawie stosownych artykułów Konwencji prawo właściwe powinno rozstrzygać jedynie o kwestii prawa do dziedziczenia, a więc odpowiadać na pytanie, czy dana osoba jest bądź nie jest spadkobiercą.

Porównując powyższą konstrukcję z rozwiązaniami przyjętymi przez Rozporządzenie nr 650/2012 $2^{71}$, można zauważyć, że zakres ten faktycznie wydaje się wąski. Wspomniane Rozporządzenie stosuje się do dziedziczenia majątku po osobach zmarłych, przy czym wyłączone jest jego stosowanie w stosunku do spraw administracyjnych, celnych i podatkowych. Akt definiuje dziedziczenie następująco: „»dziedziczenie« oznacza dziedziczenie majątku po osobie zmarłej i obejmuje wszystkie formy przejścia składników majątku, praw i obowiązków na skutek śmierci, czy to na podstawie dobrowolnego rozrządzenia na wypadek śmierci, czy to w drodze dziedziczenia ustawowego" 72 . Rozporządzenie w kwestii zakresu zastosowania prawa właściwego określa, że owemu prawu podlega „ogół spraw dotyczących spadku”"3. Można więc uznać, że akt ten traktuje pojęcie sprawy spadkowej synonimicznie z określeniem „ogół spraw dotyczących spadku”. W treści Rozporządzenia wskazano również, które kwestie w szczególności powinny być rozumiane jako objęte zakresem znaczeniowym tego pojęcia, tj. np.: kwestie otwarcia spadku, zdolności do dziedziczenia, odpowiedzialności za długi spadkowe czy działu spadku ${ }^{74}$. Treść Konwencji również zawiera normy regulujące wskazane zagadnienia, jednakże nie są one traktowane zbiorczo jako jedna kategoria, np. „ogół spraw dotyczących spadku”, jak ma to miejsce w treści Rozporządzenia. Tym samym zasada ogólna dotycząca wskazania prawa właściwego nie znajduje zastosowania automatycznie do wszystkich wymienionych kwestii. Należy jednak zaznaczyć, że z licznych przepisów Konwencji owa zasada wynika - przez odsyłanie do art. 2 i 3 , natomiast nie jest to regułą. I tak, w art. 19 Konwencji bezpośrednio określono łącznik wskazujący prawo właściwe w kwestiach zarządu spadkiem, podziału majątku spadkowego oraz działu spadku, jakim jest miejsce zwykłego pobytu spadkodawcy, wyłączając tym samym możliwość dokonania wyboru prawa, jaka gwarantowana jest przez art. 3. Powyższa analiza ukazuje, że oba

${ }^{71}$ Art. 75 ust. 3 Rozporządzenia Parlamentu Europejskiego i Rady (UE) nr 650/2012 z dnia 4 lipca 2012 r. ..., Dz.U. L 201 z 27.07.2012, s. 107-134.

72 Art. 3 ust. 1a) Rozporządzenia Parlamentu Europejskiego i Rady (UE) nr 650/2012 z dnia 4 lipca 2012 r. ..., Dz.U. L 201 z 27.07.2012, s. 107-134.

${ }^{73}$ W szwedzkiej wersji Rozporządzenia użyto sformułowania Den lag som anvisas enligt artikel 21 eller 22 ska styra arvet $i$ dess helhet, co dosłownie oznacza „dziedziczenie (lub spadek) w jego całości” i wydaje się oddawać znaczenie pojęcia „ogół spraw dotyczących spadku".

${ }^{74}$ Art. 21-23 Rozporządzenia Parlamentu Europejskiego i Rady (UE) nr 650/2012 z dnia 4 lipca 2012 r. ..., Dz.U. L 201 z 27.07.2012, s. 107-134. 
omawiane akty, biorąc pod uwagę całość ich treści, podobnie postrzegają pojęcie sprawy spadkowej, jednakże metody regulacji przyjęte w każdym z nich różnią się od siebie. Rozporządzenie proponuje znacznie bardziej kompleksowe ujęcie, podczas gdy Konwencja jedynie częściowo ustanawia ogólną zasadę wskazującą prawo właściwe w sprawach spadkowych. Wskazanie prawa właściwego w kwestiach szczegółowych regulowane jest odrębnie, a owe szczegółowe przepisy ewentualnie korespondują z ogólną zasadą przez bezpośrednie jej wskazanie czy wykorzystanie jej założeń w zmodyfikowanej wersji, co jednak nie zawsze ma miejsce.

\subsubsection{Statut spadkowy a statut rzeczowy}

Zagadnieniem, które sprawia problemy w ustawodawstwie oraz doktrynie prawa prywatnego międzynarodowego, jest kwestia jednolitości lub niejednolitości statutu spadkowego oraz relacji i wpływu statutu rzeczowego na statut spadkowy. Zróżnicowanie rozwiązań prawnych oraz instytucji prawa spadkowego w materialnym prawie spadkowym poszczególnych państw ma bezpośrednie przełożenie na definiowanie sprawy spadkowej oraz niejednolite postrzeganie zakresu statutu spadkowego. $\mathrm{Na}$ gruncie prawa prywatnego międzynarodowego statutem spadkowym określa się w ogólności prawo właściwe dla spraw spadkowych ${ }^{75}$. W kwestii statutu rzeczowego można uznać, że określa on prawo właściwe dla oceny praw i obowiązków wynikających z prawa rzeczowego oraz posiadania $^{76}$. Należy zauważyć, że o dziedziczności praw rzeczowych decyduje statut rzeczowy ${ }^{77}$, jednakże dziedziczenie praw rzeczowych, rozumiane jako przejście tych praw na następców, podlega statutowi spadkowemu. Nietrudno dostrzec potencjalny kłopot w krzyżowaniu się owych statutów, biorąc pod uwagę niejednolitość katalogu praw rzeczowych w różnych państwach, a także reguł ich powstania czy nabywania. Ponadto, sytuacją dość powszechną jest położenie poszczególnych składników majątku spadkowego w granicach więcej niż jednego państwa. Już intuicyjnie można zauważyć, że doniosłe znaczenie ma w tym przypadku kwestia dziedziczenia nieruchomości.

${ }^{75}$ Ł. Żarnowiec, Relacje między statutem rzeczowym a statutem spadkowym, w: Wpływ statutu rzeczowego na rozstrzyganie spraw spadkowych - na styku statutów, C.H. Beck, Warszawa, 2018, s. 6 .

${ }^{76}$ Szczegółowo w zakresie statutu rzeczowego zob. więcej Ł. Żarnowiec, Relacje..., s. 3.

77 J. Górecki, Prawo rzeczowe, w: System Prawa Prywatnego, T. 20B, Prawo prywatne międzynarodowe, red. M. Pazdan, C.H. Beck, Warszawa, 2015, s. 41. 
Analiza Konwencji prowadzi do wniosku, że w przypadku jej treści nie można mówić o przyjęciu jednolitego statutu spadkowego. Nie poddano bowiem dziedziczenia wszystkich składników majątku spadkowego oraz ogółu spraw dotyczących spadku jednemu prawu właściwemu wskazanemu łącznikiem personalnym, jak, ogólnie rzecz biorąc, ma to miejsce w przypadku Rozporządzenia nr 650/2012 ${ }^{78}$.

Tytułem przykładu wskazać można art. 13 Konwencji, który nie nawiązuje do ogólnej zasady wskazującej prawo właściwe w stosunku do dziedziczenia nieruchomości. Lex rei sitae zostało tu przyjęte jako właściwe przy ocenie prawa spadkodawcy do rozrządzenia nieruchomością w testamencie, w tym do dokonania zapisu na rzecz nienarodzonego dziecka, a także samej możliwości dziedziczenia nieruchomości wraz z jej przynależnościami. Warto zauważyć, że brzmienie art. 13, jako jednego z niewielu przepisów Konwencji, nie zostało zmienione Porozumieniem z $2012 \mathrm{r}$.

\subsubsection{Wybór prawa}

Powyższe omówienie treści Konwencji pozwala na stwierdzenie, że generalną zasadą jest dopuszczenie możliwości wyboru prawa właściwego dla kwestii oceny prawa do dziedziczenia. Konstrukcja art. 2 i 3 tworzy zasadę, zgodnie z którą wybór prawa dokonany przez spadkodawcę wyłącza stosowanie łącznika miejsca zwykłego pobytu spadkodawcy. Jednakże wybór ten ma charakter ograniczony. Sprowadza się on bowiem jedynie do zmiany łącznika wskazującego prawo właściwe ze zwykłego pobytu na łącznik obywatelstwa. Spadkodawca może więc zdecydować, że prawem właściwym dla dziedziczenia po nim będzie prawo tego państwa umawiającego się, którego jest obywatelem w momencie wyboru prawa bądź będzie w chwili śmierci, a gdy posiada więcej niż jedno obywatelstwo - wskazane może być prawo wybranego państwa umawiającego się. Konwencja wyraża również zasadę, że w przypadku wyboru prawa niezgodnego z powyższymi regułami, tj. wskazania prawa państwa niebędącego stroną Konwencji, ważność tego wyboru oceniana jest na podstawie prawa krajowego w każdym z umawiających się państw ${ }^{79}$.

Dopuszczenie wyboru prawa nie ma jednak charakteru uniwersalnego, wyraźnie wskazano, że zasadą jest wybór prawa w odniesieniu do prawa do dziedziczenia. Wobec obszarów, które nie są objęte zakresem tego pojęcia, Konwencja nie dopuszcza automatycznej możliwości

${ }^{78} \mathrm{~W}$ kwestii jednolitego statutu spadkowego zob. więcej Ł. Żarnowiec, Relacje..., s. 18 -26, natomiast w kwestii rozporządzenia — s. 28-34.

79 Zob. więcej M. Jänterä-Jareborg, Överenskommelsen av den 1. juni 2012..., s. 83-87. 
dokonania wyboru prawa. Przez odpowiednie stosowanie art. 3 wybór prawa jest możliwy w kontekście oceny zdolności do sporządzenia i odwołania testamentu, skuteczności dokonania czynności mortis causa takich, jak darowizna na wypadek śmierci czy zawarcie umowy spadkowej, a także oceny upływu terminu do przyjęcia spadku. Przepisy Konwencji nie wspominają jednak o możliwości dokonania wyboru prawa w kwestii dziedziczenia nieruchomości czy rozrządzenia nią w testamencie. Można więc uznać, że wybór prawa w tym przypadku nie jest dopuszczalny.

Podsumowując, na gruncie Konwencji istnieje możliwość dokonania wyboru prawa przez spadkodawcę, jednakże jest ona ograniczona do wyboru jego prawa ojczystego, będącego jednocześnie prawem jednego z państw nordyckich pozostających stronami Konwencji. Ponadto, akt limituje zakres sytuacji, w których dokonanie wyboru prawa jest możliwe.

\section{Uwagi końcowe}

Kształtowane na przestrzeni lat reguły kooperacji w ramach Rady Nordyckiej oraz sama specyfika podejścia Skandynawów do komunikacji na szczeblu międzypaństwowym prowadzą do wniosku, że współdziałanie państw nordyckich jest przykładem unikalnego i autonomicznego systemu współpracy regionalnej, opartego na zasadach wzajemnego zaufania oraz działania na rzecz wspólnego dobra. Dziedziny objęte obszarami współpracy traktowane są jako „kwestie nordyckie”, do rozwijania których niewystarczające są narzędzia, jakimi dysponują państwa w ramach polityki wewnętrznej. Konsekwentnie, przełożenie ma to również na współprace na gruncie prawnym oraz ujednolicenie prawa $\mathrm{w}$ tych państwach. Źródła procesów unifikacyjnych sięgają daleko wstecz. Zauważyć można, że formalne działania w kierunku ujednolicenia prawa nie są preferowaną metodą. Dzieje się tak z uwagi na relatywnie niedużą liczbę nordyckich konwencji oraz częste formułowanie ich postanowień w taki sposób, że ustanawiają one zasadę działania bądź konkretyzują cel, w jakim dany akt powstał, a same rozwiązania prowadzące do realizacji tego celu pozostawiane są poszczególnym państwom ${ }^{80}$.

${ }^{80}$ Owe metody wydają się respektować wewnętrzne kompetencje państw do samostanowienia, szczególnie pod względem ustawodawczym, jednakże pojawiają się tė̇ głosy krytyczne wśród skandynawskich prawników, wskazujące na brak wystarczająco kompleksowych regulacji oraz powstający na tym gruncie stan niepewności w sto- 
Niejednokrotnie obowiązywanie unijnych regulacji uniemożliwia państwom nordyckim będącym członkami UE zawieranie porozumień międzynarodowych $\mathrm{w}$ danym obszarze, zwłaszcza mających obowiązywać między nimi. Niektóre dotychczas powstałe nordyckie konwencje, szczególnie te mające za przedmiot ujednolicenie zasad prawa prywatnego międzynarodowego, aby nadal mogły być stosowane w stosunkach nordyckich, wymagały gruntownych rewizji dostosowujących ich postanowienia do kierunków i brzmienia prawa europejskiego. Przykładem może być właśnie nordycka konwencja spadkowa.

Konwencja ta nie stanowi jednak kompleksowej regulacji zagadnień prawa spadkowego. Sama konstrukcja statutu spadkowego na gruncie Konwencji jest znacznie węższa w porównaniu z uregulowaniami przyjętymi przez Rozporządzenie nr 650/2012. Warto pamiętać, że wpływ Rozporządzenia na aktualną treść Konwencji jest znaczący, co potwierdza już jej art. $1^{81}$. Przepisy Konwencji zawierają przede wszystkim normy kolizyjne wskazujące prawo właściwe dla określonych zdarzeń wchodzących w zakres statutu spadkowego. Konwencja zawiera również pojedyncze artykuły określające jurysdykcję oraz ustanawiające zasadę uznawania i wykonywania orzeczeń sądowych i ugód. Zastosowanie pewnych specyficznych rozwiązań na potrzeby porządków prawnych umawiających się państw czyni Konwencję aktem charakterystycznym ${ }^{82}$.

Pomimo problematycznej kwestii, jaką stanowi pogodzenie z sobą dwóch obszarów integracji (europejskiego oraz nordyckiego), państwa te zdołały sprawić, że współpraca w regionie nordyckim przebiega równocześnie z szeroką integracją międzynarodową. Oparty na długoletniej tradycji model nordyckiej współpracy charakteryzują efektywność i stabilność. Nie jest jednak wykluczone, że model ten w przyszłości zostanie poddany modyfikacjom. Istnieje bowiem możliwość rozszerzenia zakresu

sowaniu prawa. W kontekście skandynawskiego prawa umów zob. więcej C. Ramberg, The Hidden Secrets of Scandinavian Contract Law, „Scandinavian Studies in Law” 2007, vol. 50, s. $249-256$.

${ }^{81}$ Art. 1 Konwencji - kwestia zakresu: „chyba że co innego wynika z rozporządzenia Parlamentu Europejskiego i Rady (UE)”.

${ }^{82} \mathrm{Na}$ przykład administracja spadkiem, prawa pozostałego przy życiu małżonka oraz przysposobionego w dziedziczeniu, a także zdarzenia prawne oraz etapy, jakie mają miejsce między śmiercią spadkodawcy a podziałem masy spadkowej i przyznaniem jej składników spadkobiercom - kwestia ta uwidoczniona została w art. 19 Konwencji. Pojęcia boutredning, bodelning, och arvskifte wydają się nie mieć bezpośrednich odpowiedników w polskiej nomenklaturze. Na potrzeby niniejszego opracowania przetłumaczone zostały jako „zarząd spadkiem”, „podział majątku spadkowego” i „dział spadku”, rozgraniczając zakres pojęciowy dwóch ostatnich definicji, gdyż pierwsza z nich bardziej odpowiada faktycznemu podziałowi składników majątku spadkowego, a druga oznacza umowę, czynność prawną tego dokonującą. 
prawa Unii Europejskiej o większy obszar obejmujący państwa nordyckie, co może mieć miejsce zarówno w wyniku ewentualnego przystąpienia kolejnych państw do Unii Europejskiej, jak i zacieśnienia współpracy Norwegii i Danii z kręgiem państw unijnych w ramach „współpracy sądowej w sprawach cywilnych". W owym kontekście interesującą kwestią jest zatem zmiana, czy też kolejne zmiany, nordyckich aktów normatywnych, jak też zasad współpracy państw skandynawskich. Zagadnienie to niewątpliwie zasługuje na dalszą uwagę.

\section{Bibliografia}

\section{Publikacje}

Bernitz U., What is Scandinavian Law?, „Scandinavian Studies in Law” 2007, vol. 50.

Blomstrand S., Nordic Co-operation on Legislation in the Field of Private Law, „Scandinavian Studies in Law” 2000, vol. 39.

Bogdan M., Maunsbach U., Private International Law in Sweden, ed. 3, Wolters Kluwer, 2020.

Czepelak M., Umowa międzynarodowa jako źródto prawa prywatnego międzynarodowego, Oficyna a Wolters Kluwer business, 2008, https://sip.lex.pl/\#/ monograph/369182464/11 [Dostęp: 31.08.2021 r.].

Doliwa-Klepacki Z., Europejska integracja gospodarcza, Temida 2, Białystok, 1996.

Górecki J., Prawo rzeczowe, w: System Prawa Prywatnego, T. 20B, Prawo prywatne międzynarodowe, red. M. Pazdan, C.H. Beck, Warszawa, 2015.

Hofstede G., Hofstede G.J., Minkov M., Cultures and organizations: software of the mind: intercultural cooperation and its importance for survival, 2010.

Husa J., Nuotio K., Pihlajamäki H., Nordic Law - Between Tradition and Dynamism, ,Tilburg Institute of Comparative and Transnational Law Working Paper" 2008, no. 10.

Jänterä-Jareborg M, Behövs det särskilda internordiska regler om makars egendomsförhållanden och arv?, in: Bonus pater familias: festskrift til Peter Lødrup 70 år, 2002.

Jänterä-Jareborg M., Överenskommelsen av den 1. juni 2012 om ändring av den nordiska arvskonventionen, in: Utviklingen i nordisk arvrett - tegn i tiden, Nordisk arvrettskonferanse 24. oktober 2012, TemaNord: 2013:517, 2013.

Letto-Vanamo P., Tamm D., Nordic Legal Mind, in: Nordic Law in European Context, eds. P. Letto-Vanamo, D. Tamm, B.O.G. Mortensen, „Ius Gentium: Comparative Perspectives on Law and Justice Volume” 2019, 73. 
Maunsbach U., Sweden: Proof of and Information About Foreign Law in Civil and Commercial Matters - Swedish Perspectives, in: Treatment of Foreign Law - Dynamics towards Convergence?, ed. Y. Nishitani, „Ius Comparatum — Global Studies in Comparative Law" 2017, 26.

Mostowik P., Międzynarodowe prawo prywatne i postępowanie cywilne $w$ dekadę po wejściu w życie Traktatu Amsterdamskiego, „Przegląd Sądowy” 2010, 2.

Mostowik P., Niedźwiedź M., Druga konwencja lubańska o jurysdykcji oraz uznawaniu $i$ wykonywaniu orzeczeń $w$ sprawach cywilnych, „Kwartalnik Prawa Prywatnego" 2009, z. 4.

Parment C., The Nordic Bankruptcy Convention — an introduction, Johann Wolfgang Goethe University Frankfurt, Frankfurt, 2004, https://www.iiiglobal. org/sites/default/files/1-_Nordic_Bankruptcy_1.pdf [Dostęp: $31.08 .2021 \mathrm{r}$.].

Pazdan M., Pojęcie prawa prywatnego międzynarodowego, w: System Prawa Prywatnego, T. 20A, Prawo prywatne międzynarodowe, red. M. Pazdan, C.H. Beck, Warszawa, 2014.

Piotrowski B., Powojenna wspótpraca Skandynawów: osiagnięcia, alternatywy, prognozy na przyszłość, „Czasy Nowożytne”. 1998, nr 5.

Piotrowski B., Skandynawia współczesna w poszukiwaniu nowych dróg rozwoju 1975-2014, Wydawnictwo Naukowe UAM, Poznań, 2015.

Ramberg C., The Hidden Secrets of Scandinavian Contract Law, „,Scandinavian Studies in Law" 2007, vol. 50.

Rutkowski W., Wspótczesne państwo dobrobytu. Ekspansja, kryzys, spory, Wydawnictwo Uniwersytetu Warszawskiego, Warszawa, 2009.

Żarnowiec Ł., Relacje między statutem rzeczowym a statutem spadkowym, w: Wpływ statutu rzeczowego na rozstrzyganie spraw spadkowych — na styku statutów, C.H. Beck, Warszawa, 2018.

Den nordiska konventionen om arv, testamente och boutredning (antagen $i$ Köpenhamn 19.11.1934) En översyn av konventionsregleringen föreslagen av den nordiska expertgruppen för familjerättsfrågor, Nordiska ministerrådet, TemaNord 2013:528, 2013, http://norden.diva-portal.org/ smash/get/diva2:701659/FULLTEXT01.pdf [Dostęp: 31.08.2021 r.].

Ds 2007:006 Internationell insolvens - en diskussionspromemoria, Norstedts Juridik AB, 2007.

Svensk/engelsk ordlista för Sveriges Domstolar, Avdelningen för kompetensutveckling och internationella relationer och Kommunikationavdelningen, Domstolsverket, 2019, https://www.domstol.se/globalassets/filer/gemensamt-innehall/for-professionella-aktorer/svensk-engelsk_ordlista_2019.pdf [Dostęp: 31.08.2021 r.].

\section{Akty normatywne}

Den nordiska konventionen den 7 november 1933 om konkurs (SÖ 1934:8).

Konvention mellan Sverige, Danmark, Finland, Island och Norge om nordiska medborgares rätt att använda sitt eget språk i annat nordiskt land, Svaneke den 17 juni 1981 (SÖ 1982:93). 
Konventionen mellan Sverige, Finland, Danmark, Island och Norge undertecknad i Köpenhamn den 19 november 1934, om arv, testamente och boutredning (SÖ 1935:17).

Lag (2015:417) om arv i internationella situationer, SFS no. 2015:417.

Miljöskyddskonventionen mellan Danmark, Finland, Norge och Sverige, Stockholm den 19 februari 1974 (SÖ 1974:99).

Nordisk konvention om social trygghet Bergen den 12 juni 2012 (SÖ 2014:5).

Rozporządzenie Parlamentu Europejskiego i Rady (UE) 2015/848 z dnia 20 maja 2015 r. w sprawie postępowania upadłościowego, Dz.U. L 141 z 5.06.2015, s. $19-72$.

Rozporządzenie Parlamentu Europejskiego i Rady (UE) nr 650/2012 z dnia 4 lipca 2012 r. w sprawie jurysdykcji, prawa właściwego, uznawania i wykonywania orzeczeń, przyjmowania i wykonywania dokumentów urzędowych dotyczących dziedziczenia oraz $\mathrm{w}$ sprawie ustanowienia europejskiego poświadczenia spadkowego, Dz.U. L 201 z 27.07.2012, s. 107-134.

Rozporządzenie Rady (WE) nr 1346/2000 z dnia 29 maja 2000 r. w sprawie postępowania upadłościowego, Dz.U. L 160 z 30.06.2000, s. 1-18.

The Helsinki Treaty: Treaty of Co-operation between Denmark, Finland, Iceland, Norway and Sweden (2018:746).

Överenskommelse med Danmark, Finland, Island och Norge om ändring av den nordiska konventionen den 7 november 1933 om konkurs, Köpenhamn den 11 oktober 1977 (SÖ 1978:10).

Överenskommelse med Danmark, Finland, Island och Norge om ändring av konventionen med Finland, Danmark, Island och Norge undertecknad i Köpenhamn den 19 november 1934, SÖ 1935:17, om arv, testamente och boutredning, Köpenhamn den 1 juni 2012 (SÖ 2015:1).

Överenskommelse mellan Sverige, Danmark, Finland, Island och Norge om ändring av den nordiska konventionen den 7 november 1933 om konkurs (SÖ 1934:8 och 1978:10), Köpenhamn den 11 oktober 1982 (SÖ 1982:85). 